City University of New York (CUNY)

CUNY Academic Works

\title{
Buying Products from Whom You Know: Personal Connections and Information Asymmetry in Supply Chain Relationships
}

Ting Chen

University of Massachusetts Boston

Hagit Levy

CUNY Bernard M Baruch College

Xiumin Martin

Washington University in St. Louis

Ron Shalev

University of Toronto

\section{How does access to this work benefit you? Let us know!}

More information about this work at: https://academicworks.cuny.edu/bb_pubs/1209

Discover additional works at: https://academicworks.cuny.edu

This work is made publicly available by the City University of New York (CUNY).

Contact: AcademicWorks@cuny.edu 


\title{
Buying products from whom you know: personal connections and information asymmetry in supply chain relationships
}

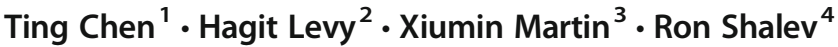

Accepted: 29 December 2020/Published online: 02 April 2021

(C) The Author(s), under exclusive licence to Springer Science+Business Media, LLC part of Springer Nature 2021

\begin{abstract}
This study investigates the role personal connections play in a crucial element of the supply chain - supplier selection. We find that the likelihood that a potential supplier (hereafter, a vendor) is selected to be an actual supplier (hereafter, supplier) increases when personal connections between executives of the vendor and the customer exist. The magnitude of the effect varies predictably across management ranks and positions and is stronger when information asymmetries between a vendor and a customer are high. Conditioning on the existence of a supply-chain partnership, a departure of a personally connected executive prompts the termination of the supply-chain relationship more often than a departure of an unconnected executive. Additional analyses show personal connections are associated with less restrictive procurement contracts and with improved customer performance after the formation of a supply-chain relationship. Overall, our study highlights the role of personal connections in reducing information asymmetry and improving operating efficiency in the supply chain.
\end{abstract}

Keywords Personal connections · Supplier selection · Supply chain · Information asymmetry

JEL G32 · G34 · L1 • M11

\footnotetext{
Ron Shalev

Ron.Shalev@rotman.utoronto.ca

Ting Chen

Ting.Chen@umb.edu

Hagit Levy

Hagit.Levy@baruch.cuny.edu

Xiumin Martin

Xmartin@wustl.edu
}

Extended author information available on the last page of the article 


\section{Introduction}

This study investigates the effect of personal connections on a key corporate decisionsupplier selection. Selecting suppliers, a critical element of a firm's supply-chain management and ultimately of its success, has become more complex in recent years, as more firms outsource larger parts of their supply chain (Yang 2009; McCarthy et al. 2013; Boyarchenko and Costello 2015). Consistent with a complex supplier-selection process, the literature on supplier selection specifies qualitative measures, such as suppliers' reputation and management quality as prominent in evaluating vendors when selecting suppliers. (See the literature review on supplier-selection criteria by Ho et al. 2010.) The rise of outsourcing in the supply chain and the need to rely on qualitative supplier-selection measures accentuate the information-asymmetry problem in supplier selection (McCarthy et al. 2013).

Because research suggests personal connections can mitigate information asymmetries in investing and financing decisions (e.g., Cohen et al. 2008; Duchin and Sosyura 2013; Engelberg et al. 2012; Fracassi 2017; Gao et al. 2014), we focus on the role personal connections play in supplier selection. McCarthy et al. (2013) note that low information asymmetries between supply-chain partners are achieved when "both parties are more inclined to trust each other, communicate more openly, and coordinate and collaborate for mutual benefits" (p. 278). If personal connections can foster trust and open communication, to mitigate information asymmetry between potential trading partners, their presence is likely to increase the likelihood of the formation of supply chain-relations, that is, to increase the likelihood of a vendor being selected as a supplier.

We identify personal connections using BoardEx, a proprietary database that reports the universities that executives attended, their employment histories, affiliations with charitable or volunteer organizations, and board of directors on which they have served. In establishing a causal relation between personal connections and a supply-chain relationship, we are mindful of a potential reverse causality, in which business relationships may lead to personal connections. Therefore, we follow Engelberg et al. (2012) and focus on personal connections that preceded the business relations by years or even decades. That is, we focus on connections formed when executives were enrolled in the same degree program at the same university and connections formed when executives worked together at the same firm before their current jobs at the supply-chain partners.

To analyze the economic effect of these connections on supplier selection, we begin with Compustat Segment file, which contains information on major customers' identities, and compile the first-time actual supplier-customer pairs. We focus on first-time supply-chain relations for two reasons. First, repeated business may foster the formation of personal connections, creating reverse-causality concerns. First-time relations are less prone to this issue. Second, focusing on first-time relations can mitigate serialcorrelation concerns in the empirical analysis. For every first-time supplier-customer pair, we then seek to identify vendors that the same customer considers alternatives to the chosen supplier. Ideally, we should include the actual vendors a customer considers in the vetting process. However, given that this information is unobservable, deciding which vendors to include becomes challenging and subjective. For the main empirical analyses, following Erel et al. (2019), we rely on revealed preferences and use the 
Mahalanobis distance method to identify two vendors closest in relevant, observable attributes (i.e., four-digit SIC code, firm size, sales, and profitability) to the selected supplier. Recognizing the subjectivity of our choice, we also conduct batches of robustness tests by altering the attributes we match on and the number of vendors to match with the selected supplier. Our results are robust to these choices.

We first show that the likelihood of a vendor becoming a supplier increases if the customer and vendor executives are personally connected. This result holds for personal connections formed through both education and prior employment. The existence of personal connections increases the likelihood of a vendor being selected as a supplier by $60 \%$ of the baseline probability. As discussed earlier, we address the reversecausality issue by focusing on education-based and prior work-based personal connections. However, because supplier selection may involve multiple unobservable factors, endogeneity may still be a concern. We employ multiple strategies to alleviate this concern. First, we test whether the effect of personal connections varies predictably across different ranks and positions of executives. We find that connections between top-level executives (C-Level) exhibit statistically stronger effects than those between lower-level executives. In addition, connections involving a customer's $\mathrm{COO}$ - who oversees the supply chain in most firms - have a more pronounced effect on supplier selection than connections involving a CEO or CFO. Second, we employ an exogenous shock to personal connection - a departure of a connected executive-and test whether this shock prompts the termination of the business relations. The idea is that the loss of personal connections may weaken the trust and open communication between trading partners, resulting in an increase of information asymmetry and thus an earlier termination of the business relations. We find that customer-supplier relations end earlier after a departure of a connected executive than after a departure of an unconnected one. Finally, we conduct multiple sensitivity analyses to further address endogeneity and reverse causality, which we describe and tabulate in the online appendix.

Although we have conducted batches of sensitivity tests discussed above, we acknowledge that no test can rule out endogeneity in empirical studies such as ours and that empirical choices we made, in particular with respect to the selection of nonsupplier vendors, may have led to our results. Thus our results should be read with caution, subject to the remaining concern that we have not considered all possible endogenous factors.

After providing robust evidence that personal connections affect the formation of supply-chain relations, we conduct cross-sectional tests to illuminate how personal connections affect supplier selection. If personal connections improve the customer's knowledge about her connected vendor and thus reduce information asymmetry, we predict that the relation between personal connections and the likelihood of a vendor becoming a supplier will be stronger when ex ante information symmetry is higher. Using two proxies for information asymmetry - the geographical distance between customers and vendors and vendors' accounting quality (measured by unsigned abnormal accruals) — we find evidence consistent with this prediction. These results suggest personal connections facilitate soft-information transmission between supply-chain partners, thereby expanding firms' geographical boundaries and mitigating frictions arising from firms' poor-quality hard information.

Whereas our study focuses on the effect of personal connections on supplier selection, we also explore two dimensions of their consequences. First, we examine 
the effect of personal connections on provisions in procurement contracts. Costello (2013) suggests provisions in procurement contracts are designed to mitigate information asymmetries between the customer and supplier. Using a hand-collected sample of procurement contracts, we find that procurement contracts between personally connected supply-chain partners are likely to be less restrictive to the supplier and to have longer contract duration. This evidence suggests informal personal relationships between executives may substitute formal contracting, which again is consistent with the role of personal connections in mitigating information frictions. Second, we investigate the effect of personal connections on customer operating efficiency. We identify four aspects of operating efficiency that are likely to be affected by the quality of supplier selection: inventory-supply interruptions (measured by the volatility of inventory levels), inventory overstocking (measured by the volatility of the cost of goods sold), sales efficiency (measured as the ratio of sales to assets), and overall operating performance (measured by ROA). We find all four measures improve after the formation of a supply-chain relationship involving a personally connected supplier.

Our study contributes to the literature in three important ways. First, our findings highlight the importance of personal connections in a critical firm operating decision. Our results show personal connections increase a vendor's chance of being selected as a supplier. Second, our findings highlight the role of personal connections in transmitting soft information and expanding geographical constraints along supply chains, complementing research documenting their importance to mutual fund managers' investment decisions (Cohen et al. 2008) and firms' external financing decisions (Engelberg et al. 2012). Last, we show personal connections relax procurement-contract terms and improve firms' operating efficiency. These findings not only corroborate the evidence that personal connections can alleviate informational frictions but also offer additional insights into the contracting literature and, perhaps more importantly, highlight the real value that personal connections create.

The rest of the paper is organized as follows. The next section reviews the literature and develops testable hypotheses. Section 3 discusses sample selection. Section 4 presents empirical results and additional analyses. Section 5 concludes.

\section{Hypothesis development}

Customer-supplier relationships are widely recognized as an important part of supplychain management. Sarkis and Talluri (2002) argue: "One of the critical challenges faced by purchasing managers is the selection of strategic partners that will furnish their firms with the necessary products, components, and materials in a timely and effective manner to help maintain a competitive advantage" (p. 18). Research documents that the influence of customer-supplier relationships transcends the provision of products and services, affecting firm capital structure (Kale and Shahrur 2007), liquidity management (Cohen and Li 2014; Cohen and Li 2017; Costello 2017), and financial-reporting policy (Hui et al. 2012). 
Supply-chain risks can stem from multiple sources, such as an increase in the price of supplier inputs or of financing costs, ${ }^{1}$ a supplier setback such as a plant fire, a supplier re-allocation of its product capacity because of a change in demand to its products, ${ }^{2}$ or a supplier's bankruptcy. ${ }^{3}$ Operations research suggests a few waysoperational or contractual - to mitigate these risks (Yang 2009; Anupindi and Akella 1993; Tomlin 2006; Babich et al. 2005; Babich et al. 2007; Serel et al. 2001; Kouvelis and Milner 2002; Babich 2006). However, the mechanisms these studies suggest are either too costly to implement or cannot effectively shield a customer from all the risks involved. Thus these risks must be evaluated when selecting a supplier.

In recent years, more firms have moved toward integrated supply chains, in which larger parts of the supply chain are outsourced (Yang 2009; McCarthy et al. 2013; Boyarchenko and Costello 2015). The move has accentuated supply-chain risks and increased the complexity of the supplier-selection process, which leads customers to employ softer measures to evaluate vendors. Research argues these measures better mitigate supply-chain risks than focusing only on price (e.g., Ittner et al. 1999). The literature on supplier selection reports multiple soft vendor evaluation criteria that are prominent among customers selecting suppliers. Factors such as product quality, reputation, and position in industry (e.g., Liu et al. 2000; Weber et al. 2000; Bevilacqua et al. 2006; Chou and Chang 2008; Demirtas and Üstün 2009), and delivery reliability/ on-time delivery (e.g., Liu et al. 2000; Weber et al. 2000; Çebi and Bayraktar 2003; Perçin 2006; Demirtas and Üstün 2009) are ranked first and second among the evaluating criteria covered in the supplier-selection literature, whereas price/cost ranks only third. (See a review of the literature by Ho et al. 2010.) Other qualitative factors that the supplier-selection literature views as important are manufacturing capability (e.g., Liu et al. 2000; Sevkli et al. 2007; Demirtas and Üstün 2009) and management (e.g., Chen and Huang 2007; Sevkli et al. 2007). These evaluation measures employed in supplier selection accentuate the importance of soft information and informal channels of acquiring information by customers.

Consistent with research that shows personal connections improve the transmission of soft (private) information between firms and fund managers (Cohen et al. 2008), lenders and borrowers (Engelberg et al. 2012), headquarters and division managers (Duchin and Sosyura 2013), and board members (Fracassi 2017), we argue personal connections may also be influential in the supplier-selection process. Because customers' executives with personal connections may already have extensive knowledge of the connected vendor's operations through informal interactions, this knowledge likely mitigates information asymmetry between them and helps a customer more accurately assess supply-chain risks. In addition, after the formation of a supplychain relationship, personal connections can not only reduce the costs and improve the effectiveness of monitoring the supplier but also allow the customer to receive

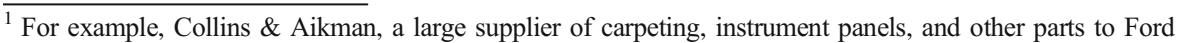
Motors, halted shipment in 2006 over a dispute about a price increase that was part of the supplier's effort to stave off bankruptcy after filing for Chapter 11 protection in 2005 (McCracken 2006).

${ }^{2}$ For example, Beckman Coulter, a medical device manufacturer, lost its supplier, Dovatron, after Flextronics acquired Dovatron in 2000. After the acquisition, Flextronics restructured Dovatron to focus on higher-volume products and decided it would no longer serve Beckman Coulter (Yang 2009).

${ }^{3}$ Yang (2009) provides the example of the bankruptcy of UPF-Thompson, the sole provider of chassis for Land Rover's Discovery model.
} 
timely updates of suppliers' shocks, which in turn enables her to take timely actions to minimize her exposure to supply-chain risks. Due to these benefits, we hypothesize the following.

The likelihood that a vendor becomes a supplier increases if personal connections exist between the vendor's and the customer's executives.

\section{Sample selection, identification, and descriptive statistics}

\subsection{Sample selection}

To construct the sample for the supplier-selection analysis (the main analysis), we start with the Compustat Industry Segment file and identify first-time customer-supplier relations among U.S. public firms with available data from year 2000 through 2011. The file contains information about sales to major customers. Suppliers report this in footnotes under SFAS 14 and SFAS 131. The threshold for mandatory reporting is that a customer accounts for at least $10 \%$ of the reporting firm's total sales. However, the file also contains voluntary disclosures of major customers that account for less than $10 \%$ of sales. Because suppliers that choose to report customers that represent less than $10 \%$ of their sales may not be random, we exclude them from the sample. We also exclude suppliers that do not disclose the identity of their major customers. ${ }^{4}$ We then merge the sample with the BoardEx database. ${ }^{5}$ BoardEx reports work histories, educations, and participation in social organizations for C-level (e.g., CEO and CFO) executives, lower-level executives, and current directors. It is widely used in academic studies that examine the effect of personal connections on business decisions (e.g., Engelberg et al. 2012; Schmidt 2015; Fracassi and Tate 2012). We focus on the period starting from year 2000, because, before 2000, BoardEx's coverage of U.S. public firms is very limited (Engelberg et al. 2012; Fracassi and Tate 2012). We then expand the sample by including vendors that the customer likely considered but did not select as a supplier (nonsupplier vendors).

One drawback of using segment data to identify the start of customer-supplier relations is that the dataset includes only large customers (i.e., those exceeding $10 \%$ of the supplier's sales). Thus the start date of the relationship may have been earlier than when it was first disclosed in the filings, which could mean that a personal connection that we identify as preceding the supply-chain relationship may have been formed after the business relations started. To mitigate concerns about this reverse causality, we follow Engelberg et al. (2012) by focusing on two types of personal connections that likely precede business relations: educational connections and prior work-based connections. Similar to Cohen et al. (2008), we classify two executives as having an educational connection if they attended the same university, overlapped at

\footnotetext{
${ }^{4}$ Ellis et al. (2012) suggest more than $20 \%$ of firms that report the existence of a major customer do not disclose its identity.

${ }^{5}$ We thank Joseph Engelberg for providing us with the CRSP-Compustat-BoardEx link file.
} 
least one year, and received the same degree. ${ }^{6}$ Consistent with Engelberg et al. (2012), we classify two executives as having a work-based connection if they worked for the same employer before the employment at the current customer and vendor. We also require personal connections to predate the reported start date of the business relations by at least two years. To verify that our choices are appropriate, we randomly select 50 observations and search the web and the Factiva database for the first mention of the customer-supplier relations. In all 50 cases, the personal connection precedes the first mention of the business relations. We then obtained financial data from Compustat and stock return data from CRSP.

\subsection{Identification of nonsupplier vendors}

To test the effect of personal connections on supplier selection, we need to identify potential suppliers that were not selected as suppliers (nonsupplier vendors). To draw proper inferences, the nonsupplier vendors we identify must be comparable to the supplier and thus be realistic candidates for the customer to consider. Identifying suppliers is very costly for customers and involves reference checks of financial status checks, the ability to meet specifications, product or service quality, and so on (Beil 2010). The more vendors the customer considers, the higher the cost of search. Thus customers typically consider a small set of vendors when selecting a supplier. Ideally, we could include the full set of vendors that the customer actually considered. However, given that this information is unobservable, we attempt to identify, based on revealed preference, vendors that were likely considered but were not selected. This approach resembles that of Erel et al. (2019). To find a group of directors that are comparable to the nominated directors, Erel et al. (2019) construct a candidate pool comprising directors who, within one year of the appointment, joined the board of a smaller neighboring firm of the focal firm. Similarly, we select nonsupplier vendors within the four-digit SIC code of the supplier that most resemble the selected vendor (i.e., the supplier). The assumption is that the potential supplier candidates the customer considers resemble the actual supplier, based on her revealed preferences. To be considered a nonsupplier vendor in our sample, a firm must satisfy an additional preliminary requirement: it must have data available on BoardEx. We then use the Mahalanobis distance approach to identify up to two nonsupplier vendors from the same four-digit SIC industry and the same fiscal year that are closest to the supplier with respect to size (total assets), performance (ROA), and sales.

We acknowledge that the focus on the above three factors is somewhat exploratory and lacks theoretical support and that customers may consider additional factors when winnowing the list of potential suppliers. However, as reported in Table 1, matching based on the three factors yields a list of vendors that are also comparable to the actual supplier across multiple other factors. Therefore these three factors seem to do a good job of parsimoniously encompassing firms' underlying fundamentals, which the customer likely considers when selecting a supplier.

Because some industries defined as four-digit SICs have fewer than three firms, we identify suitable nonsupplier vendors for 1430 suppliers, for a total of 2630 nonsupplier vendors. The

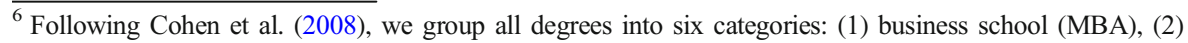
medical school, (3) general graduate (MA or MS), (4) $\mathrm{PhD}$, (5) law school, and (6) general undergraduate.
} 
Table 1 Descriptive Statistics-Sample Partitioned by Customer-Supplier and Customer-Nonsupplier Vendor Pairs

\begin{tabular}{|c|c|c|c|c|c|c|c|}
\hline & \multicolumn{3}{|c|}{$\begin{array}{l}\text { Customer-Nonsupplier Vendor Pairs } \\
(N=2630)\end{array}$} & \multicolumn{3}{|c|}{$\begin{array}{l}\text { Customer-Supplier Pairs } \\
(N=1430)\end{array}$} & \multirow[t]{2}{*}{ Diff } \\
\hline & Mean & STD & Median & Mean & STD & Median & \\
\hline TANGIBILITY_S & 0.221 & 0.232 & 0.133 & 0.219 & 0.236 & 0.129 & 0.002 \\
\hline $\mathrm{CASH}_{-} \mathrm{S}$ & 0.302 & 0.265 & 0.228 & 0.303 & 0.263 & 0.242 & -0.001 \\
\hline SIZE_S & 5.601 & 1.580 & 5.524 & 5.581 & 1.681 & 5.496 & 0.021 \\
\hline$R O A \_S$ & 0.009 & 0.048 & 0.020 & 0.007 & 0.054 & 0.019 & 0.002 \\
\hline$L E V \_S$ & 0.186 & 0.237 & 0.109 & 0.191 & 0.256 & 0.108 & -0.005 \\
\hline$L O G \_S A L E \_S$ & 5.137 & 1.775 & 5.209 & 5.151 & 1.796 & 5.137 & -0.014 \\
\hline$I V Y \_L E A G U E \_S$ & 0.163 & 0.262 & 0.000 & 0.162 & 0.262 & 0.000 & 0.001 \\
\hline PHD_MASTERS_S & 0.509 & 0.365 & 0.500 & 0.497 & 0.348 & 0.500 & 0.011 \\
\hline LARGEST_S & 0.049 & 0.217 & 0.000 & 0.050 & 0.219 & 0.000 & -0.001 \\
\hline SALE_GROWTH_S & 0.230 & 0.792 & 0.083 & 0.261 & 0.839 & 0.098 & -0.031 \\
\hline$G M \_S$ & 0.345 & 0.438 & 0.408 & 0.379 & 0.395 & 0.412 & $-0.034^{* *}$ \\
\hline$P M \_S$ & -0.136 & 0.375 & 0.013 & -0.149 & 0.382 & 0.007 & 0.013 \\
\hline CAPEX_S & 0.051 & 0.068 & 0.028 & 0.053 & 0.071 & 0.028 & -0.003 \\
\hline$D A Y S \_I N V \_S$ & 67.667 & 79.840 & 45.158 & 71.586 & 81.536 & 51.298 & -3.918 \\
\hline$D A Y S \_A P \_S$ & 75.992 & 119.344 & 44.257 & 82.875 & 117.032 & 47.839 & $-6.883^{*}$ \\
\hline$D A Y S \_A R \_S$ & 63.690 & 41.914 & 57.621 & 63.069 & 41.083 & 56.327 & 0.622 \\
\hline PPE_TO_S & 12.065 & 19.771 & 5.636 & 13.154 & 22.774 & 5.896 & -1.089 \\
\hline$I H L D \_S$ & 0.083 & 0.102 & 0.044 & 0.085 & 0.100 & 0.052 & -0.002 \\
\hline$N E G F C F \_S$ & 0.434 & 0.496 & 0.000 & 0.461 & 0.499 & 0.000 & $-0.027^{*}$ \\
\hline$R N D \_S$ & 0.090 & 0.124 & 0.042 & 0.097 & 0.135 & 0.052 & $-0.007 *$ \\
\hline$A G E \_S$ & 2.533 & 0.749 & 2.485 & 2.431 & 0.769 & 2.398 & $0.101 * * *$ \\
\hline$A G E_{-} C$ & 3.423 & 0.640 & 3.638 & 3.432 & 0.636 & 3.638 & -0.009 \\
\hline$S I Z E_{-} C$ & 10.253 & 1.218 & 10.370 & 10.257 & 1.226 & 10.368 & -0.005 \\
\hline DISTANCE (miles) & 1151.466 & 930.485 & 927.174 & 1091.372 & 974.382 & 848.855 & $60.094 *$ \\
\hline DISTANCE $(L N)$ & 6.439 & 1.522 & 6.833 & 6.260 & 1.690 & 6.745 & $0.179 * * *$ \\
\hline$A B N \_A C C R U A L \_S$ & 0.138 & 0.186 & 0.089 & 0.142 & 0.164 & 0.096 & -0.004 \\
\hline
\end{tabular}

This table reports descriptive statistics of major firm fundamentals for the supplier-selection sample $(N=$ 4060). For each customer-supplier pair, we include up to two customer-nonsupplier vendor pairs. Customernonsupplier pairs include the customer of the customer-supplier pair and one of the two closest nonsupplier vendors to the supplier, within the same four-digit SIC code and fiscal year, with respect to total assets, ROA, and sales. We use the Mahalanobis distance procedure to identify the two closest nonsupplier vendors. The sample is partitioned based on whether the vendor is a supplier. In total, we have 1430 actual customersupplier pairs and 2630 customer-nonsupplier pairs. Variable definitions are provided in Appendix Table 10. $* * *, * *$, and $*$ denote two-tailed significance at the $0.01,0.05$, and 0.10 levels, respectively.

number of suppliers and nonsupplier vendors implies a baseline average probability of $\sim 35 \%$ that a vendor will be selected as a supplier. Table 1 reports statistics on major firm fundamentals for the sample partitioned based on whether a vendor is a supplier. We compare suppliers with nonsupplier vendors across a comprehensive set of firm fundamentals that may 
affect supplier selection. Statistics show that, except for a few variables (e.g., supplier gross margin and age), nonsupplier vendors and suppliers are similar in most fundamental characteristics, suggesting the three variables employed in the Mahalanobis distance approach do a good job matching the nonsupplier vendors with suppliers. To further alleviate the concern that these firm characteristics might drive our results, we include all of them as control variables in regression analyses.

Note that, relative to the supplier firms, matched nonsupplier vendors are slightly farther away from the customer firm. If a firm chooses her suppliers based on distance and distance happens to be correlated with personal connections, distance might constitute a correlated omitted variable. To address this possibility, we include distance as a control variable in all regression analyses. We further construct an alternative sample by matching nonsupplier vendors with suppliers based on their distance from the customer firm. This alternative matching procedure eliminates the difference in the distance between supplier-customer pairs and nonsupplier-customer pairs. Our results reported in online appendix, Table A4, are robust to this alternative sample.

\subsection{Descriptive statistics}

Table 2 reports summary statistics of personal connections for our baseline supplierselection sample $(N=4060)$ consisting of both customer-supplier pairs and customernonsupplier vendor pairs. Panels A and B focus on the source of connections and the role of the connected executives in a firm, respectively. Panel A shows that $7.4 \%$ of our sample have educational connections, $16.3 \%$ have past-work connections, and $21 \%$ have either educational connections or past-work connections. Connections through current employment or board memberships exist for $3.3 \%$ of the sample. These statistics suggest the connections on which we focus are common in the product market. Conditioning on the existence of at least one educational connection between a pair of firms, the average number of educational connections is 1.24 , and that of pastwork connections is not surprisingly higher, 2.86. Interestingly, the corresponding number for current work connections and board memberships is 43 , which is much higher than the other two types of connections. This observation suggests these connections may have resulted from the supply-chain relations and thus may pose a reverse-causality concern. To mitigate this concern, we focus on educational and pastwork connections hereafter and exclude connections through current work and board memberships. We also exclude connections through charities and other volunteer groups, due to the same concerns about reverse causality. Panel B shows that $0.5 \%$ of the sample observations have connections between CEOs, $1.9 \%$ have connections between $\mathrm{C}$-level executives at both firms, and $15.2 \%$ have connections between non-C level executives at both firms. Customers' CEOs (CFOs) are connected with vendor executives at all rank levels for $2.2 \%(1.2 \%)$ of the sample, and customers' COOs are connected in $0.7 \%$ of the sample.

Table 3 reports summary statistics of personal connections for the sample partitioned based on whether the vendor is also a supplier. Though the average number of executives per firm reported on BoardEx is comparable between suppliers and nonsupplier vendors, the percentage of suppliers that are personally connected is greater than the percentage of nonsupplier vendors (educational connections: $10 \%$ versus 6\%; past-work connections: $23 \%$ versus $12.7 \%$ ). We find similar results when 
Table 2 Descriptive Statistics - Type of Personal Connections

Panel A: Type of Personal Connections

\begin{tabular}{|c|c|c|c|c|c|c|c|c|}
\hline & \multicolumn{2}{|l|}{1} & \multicolumn{2}{|l|}{2} & \multicolumn{2}{|l|}{3} & \multicolumn{2}{|l|}{4} \\
\hline & \multicolumn{2}{|c|}{ CON_EDU } & \multicolumn{2}{|c|}{ CON_WORK } & \multicolumn{2}{|c|}{ CONNECTED } & \multicolumn{2}{|c|}{$\begin{array}{l}\text { Current Work and Board } \\
\text { Memberships }\end{array}$} \\
\hline & Mean & STD & Mean & STD & Mean & STD & Mean & STD \\
\hline Connection $(1 / 0)$ & 0.074 & 0.262 & 0.163 & 0.369 & 0.210 & 0.407 & 0.033 & 0.177 \\
\hline Number of Connections & 0.092 & 0.352 & 0.456 & 2.654 & 0.559 & 2.767 & 1.400 & 11.816 \\
\hline $\begin{array}{l}\text { Number of Connections } \\
\text { if Connection }=1\end{array}$ & 1.243 & 0.494 & 2.864 & 6.144 & 2.667 & 5.563 & 43.068 & 50.177 \\
\hline \multicolumn{9}{|c|}{ Panel B: Management-Level Connections } \\
\hline & \multicolumn{2}{|c|}{1} & \multicolumn{2}{|l|}{2} & \multicolumn{2}{|l|}{3} & \multicolumn{2}{|l|}{4} \\
\hline & \multicolumn{2}{|c|}{ CEO-CEO } & \multicolumn{2}{|c|}{ C Level } & \multicolumn{2}{|c|}{ Non-C Level } & \multicolumn{2}{|c|}{ CUST_CEO } \\
\hline & Mean & STD & Mean & STD & Mean & STD & Mean & STD \\
\hline Connection $(1 / 0)$ & 0.005 & 0.071 & 0.019 & 0.136 & 0.152 & 0.359 & 0.022 & 0.144 \\
\hline Number of Connections & 0.005 & 0.075 & 0.023 & 0.185 & 0.370 & 2.343 & 0.028 & 0.268 \\
\hline \multirow{4}{*}{$\begin{array}{l}\text { Number of Connections } \\
\text { if Connection }=1\end{array}$} & 1.048 & 0.218 & 1.240 & 0.560 & 2.443 & 5.585 & 1.314 & 1.311 \\
\hline & 5 & & 6 & & & & & \\
\hline & \multicolumn{2}{|c|}{ CUST_CFO } & \multicolumn{2}{|c|}{ CUST_COO } & & & & \\
\hline & Mean & STD & Mean & STD & & & & \\
\hline Connection $(1 / 0)$ & 0.012 & 0.110 & 0.007 & 0.084 & & & & \\
\hline Number of Connections & 0.016 & 0.191 & 0.011 & 0.148 & & & & \\
\hline $\begin{array}{l}\text { Number of Connections } \\
\text { if Connection }=1\end{array}$ & 1.294 & 1.171 & 1.567 & 0.817 & & & & \\
\hline
\end{tabular}

Panel A of this table reports summary statistics on the types of personal connections reported in BoardEx for all customer-supplier pairs and customer-nonsupplier vendor pairs in the supplier-selection sample $(N=4060)$. Column 1 reports the mean and standard deviation for educational connections (CON_EDU), which require that the two executives attended the same school, overlapped for at least one year, and received the same degree (e.g., MBA). Column 2 reports statistics for connections through past work (CON_WORK), which requires that the two executives overlapped at the same firm for at least one year before their tenures at the customer and vendor. Column 3 reports statistics for a connection variable that combines both educational and past-work connections (CONNECTED). The connections defined in columns 1, 2, and 3 are the variables of interest throughout the empirical tests. Column 4 reports statistics for the work connections that were established while one of the executives worked for either the vendor or the customer and the connections that were established while serving on the same corporate board(s). The connections in column 4 are excluded from the analysis due to reverse-causality concerns.

Panel B of this table reports summary statistics on the management level of personal connections reported in BoardEx for all customer-supplier pairs and customer-nonsupplier vendor pairs $(N=4060)$. The connections correspond to the connections analyzed in Table 5. Column 1 reports the mean and standard deviation for personal connections between CEOs at the customer and vendor pairs. Column 2 reports statistics for connections between two C-Level (e.g., CEO, CFO, and COO) officers at the customer-vendor pairs. Column 3 reports statistics for connections between non-C-Level officers. Column 4 reports statistics for connections between customers' CEOs and vendor executives at all rank levels. Column 5 reports statistics for connections between customers' CFOs and vendor executives at all rank levels. Column 6 reports statistics for connections between customers' COOs and vendor executives at all rank levels. 
Table 3 Summary Statistics - Type of Personal Connections: Sample Partitioned by Customer-Supplier and Customer-Nonsupplier Vendor Pairs

\begin{tabular}{|c|c|c|c|c|c|c|c|c|c|}
\hline & \multicolumn{4}{|c|}{$\begin{array}{l}\text { Customer-Nonsupplier } \\
\text { vendor Pairs }(N=2630)\end{array}$} & \multicolumn{4}{|c|}{$\begin{array}{l}\text { Customer-Supplier } \\
\text { Pairs }(N=1430)\end{array}$} & \multirow[t]{2}{*}{ DIFF } \\
\hline & Mean & STD & MED & $\mathrm{N}$ & Mean & STD & MED & $\mathrm{N}$ & \\
\hline $\begin{array}{l}\text { Number of executives } \\
\text { in BoardEx }\end{array}$ & 10.735 & 7.778 & 9.000 & 2630 & 10.784 & 8.218 & 9.000 & 1430 & -0.049 \\
\hline \multicolumn{10}{|l|}{$C O N \_E D U$} \\
\hline Connection $(1 / 0)$ & 0.060 & 0.238 & 0.000 & 2630 & 0.100 & 0.300 & 0.000 & 1430 & $-0.040 * * *$ \\
\hline Number of Connections & 0.075 & 0.318 & 0.000 & 2630 & 0.124 & 0.406 & 0.000 & 1430 & $-0.050^{* * *}$ \\
\hline $\begin{array}{l}\text { Number of Connections } \\
\text { if Connection }=1\end{array}$ & 1.250 & 0.502 & 1.000 & 158 & 1.247 & 0.506 & 1.000 & 143 & -0.004 \\
\hline \multicolumn{10}{|l|}{ CON_WORK } \\
\hline Connection $(1 / 0)$ & 0.127 & 0.333 & 0.000 & 2630 & 0.230 & 0.421 & 0.000 & 1430 & $-0.103^{* * *}$ \\
\hline Number of Connections & 0.323 & 1.347 & 0.000 & 2630 & 0.731 & 4.147 & 0.000 & 1430 & $-0.408^{* * * *}$ \\
\hline $\begin{array}{l}\text { Number of Connections } \\
\text { if Connection }=1\end{array}$ & 2.534 & 2.931 & 1.000 & 333 & 3.124 & 8.077 & 2.000 & 329 & -0.627 \\
\hline \multicolumn{10}{|l|}{ CONNECTED } \\
\hline Connection (1/0) & 0.169 & 0.375 & 0.000 & 2630 & 0.284 & 0.451 & 0.000 & 1430 & $-0115 * * *$ \\
\hline Number of Connections & 0.398 & 1.414 & 0.000 & 2630 & 0.856 & 4.235 & 0.000 & 1430 & $-0.458^{* * * *}$ \\
\hline $\begin{array}{l}\text { Number of Connections } \\
\text { if Connection }=1\end{array}$ & 2.351 & 2.692 & 1.000 & 445 & 3.015 & 7.534 & 2.000 & 406 & $-0.664 *$ \\
\hline
\end{tabular}

This table reports descriptive statistics on personal connections reported in BoardEx for all customer-supplier pairs and customer-nonsupplier vendor pairs $(N=4060)$ partitioned by whether a vendor is a supplier. For each connection variable (CON_EDU,CON_WORK, and CONNECTED), we report statistics on the percentage of pairs in the partition that have a personal connection, the average number of connections in the partition, and the average number of connections when at least one connection exists. Diff is the difference between the two partitions. $* * *, * *$, and $*$ denote two-tailed significance at the $0.01,0.05$, and 0.10 levels, respectively.

we consider the number of connections between a pair of firms. This preliminary evidence suggests personal connections may affect supplier selection.

\section{Empirical analyses}

\subsection{The effect of personal connections on customers' choice of suppliers}

To test our hypothesis of the effect of personal connections on the selection of suppliers, we estimate the model specified as follows.

$$
\begin{aligned}
& \text { SUPPLIER }_{i, j, t}=\beta_{0}+\beta_{1} * \text { CONNECTED }_{i, j, t}+\beta_{2} * \text { DISTANCE }_{i, j, t} \\
& +\beta_{l} * \text { VEND_CONTROLS } S_{l, j, t}+\beta_{m} * \text { CUST_CONTROLS } S_{m, i, t} \\
& +\gamma_{i}{ }^{*} \text { CUSTOMER-YEAR_FE } E_{i}+\varepsilon_{i, j, t}
\end{aligned}
$$


where $S U P P L I E R_{i, j, t}$ is an indicator variable that takes the value of 1 if a vendor $j$ is also a supplier of customer $i$ at year $t$ and 0 otherwise. The subscripts $i, j$, and $t$ index for customer $i$, vendor $j$, and fiscal year $t$. The main variable of interest is CONNECTED $D_{i, j, t}$. It takes the value of 1 if at least one educational or work-based connection between the customer's ( $i$ 's) executives and the vendor's ( $j$ 's) executives exists and 0 otherwise. We use a dichotomous coding for personal connections throughout the empirical analyses, because it provides the most intuitive interpretation of the results. For robustness, we also report the baseline results for educational $\left(C O N \_E D U_{i, j, t}\right)$ and past-work connections $\left(C O N \_W O R K_{i, j, t}\right)$, measured separately, and for the number of connections (measured as the natural logarithm of one plus the number of connections between a vendor and a customer).

DISTANCE $E_{i, j, t}$ is the natural logarithm of the distance in miles between the zip code of the customer headquarters and that of the vendor headquarters. We include this variable because distance is likely to relate to delivery time and costs (Winter 1988; Sarkis and Talluri 2002). A longer distance between the two firms is also likely to be associated with a larger information gap between the customer and the vendor.

We control for a large set of vendor characteristics $\left(V E N D_{-} C O N T R O L S_{l, \mathrm{j}, t}\right)$ identified in the supply-chain literature to alleviate the correlated omitted-variable concern. The control variables in our model are based on the supplier-selection literature that identifies prominent factors that customers consider when evaluating vendors in supplier selection. These factors are as follows: (1) product quality and reputation in the product market (Liu et al. 2000; Weber et al. 2000; Demirtas and Üstün 2009), which we control for using age, sales, and dominance in its product market; (2) delivery reliability/on-time delivery (Liu et al. 2000; Weber et al. 2000; Demirtas and Üstün 2009), which we control for by the distance between the customer and vendor; (3) product price/competitiveness of cost (Liu et al. 2000; Weber et al. 2000; Demirtas and Üstün 2009), which we control for by gross margin and operating margin; (4) manufacturing capability (Liu et al. 2000; Sevkli et al. 2007; Demirtas and Üstün 2009), which we control for by capital expenditure and asset tangibility; (5) management (Chen and Huang 2007; Sevkli et al. 2007), which we control for by the ratio of executives graduating from top universities; (6) manufacturing technology/technical capability (Liu and Hai 2005; Chen and Huang 2007; Sevkli et al. 2007), which we control for by the ratio of executives with doctorates and master's degrees; (7) research and development (Sevkli et al. 2007; Demirtas and Üstün 2009), which we control for by R\&D intensity; (8) financial strength/risk (Muralidharan et al. 2002; Liu and Hai 2005; Chen and Huang 2007), which we control for by cash holdings, leverage, return on assets, sales growth, and negative cash flow; and (9) production flexibility/flexibility of the response to customer requests (Muralidharan et al. 2002; Sarkis and Talluri 2002; Demirtas and Üstün 2009), which we control for by inventory holding period, PP\&E turnover, days of accounts receivable, days of accounts payable, and days of inventory. We include customer-year fixed effects and thus do not include customer-specific controls. Appendix Table 10 provides a detailed definition of all variables used. We follow Bauer et al. (2018), where applicable, in measuring control variables.

$\mathrm{Ai}$ and Norton (2003) note that nonlinear fixed-effects models generate biased estimates for interaction terms. To mitigate these biases and enable a more intuitive interpretation of the economic magnitude of the coefficients, we focus on a linear probability model using ordinary least squares (OLS) to test the hypothesis. Duchin and 
Sosyura (2014) adopt a similar approach. We verify, however, that the magnitude of the effect in the OLS regression resembles the one in a probit regression.

Table 4 reports results of the analysis based on the baseline supplier-selection sample $(N=4060)$, which includes customer-supplier and customer-nonsupplier vendor pairs identified using the Mahalanobis-distance approach. We vary the measurement of personal connections across columns. In columns 1 and 2, personal connections are measured as an indicator variable that takes the value of 1 for the existence of personal connections and 0 otherwise. In columns 3 and 4, they are measured as the natural logarithm of one plus the number of connections. In columns 1 and 3, the personal-connections measure captures both work-based connections and educational connections (CONNECTED), and, in columns 2 and 4, each type of personal connection is measured individually ( $C O N_{-} W O R K$ and $C O N_{-} E D U$ ). The coefficients on connection variables, CONNECTED, CON_EDU, and CON_WORK, are positive and significant at the $5 \%$ level or better across all specifications. Results in column 1coefficient on CONNECTED of $0.21^{7}$ - suggest the existence of a personal connection increases the likelihood of being selected as a supplier by $21 \%$, representing a $60 \%$ increase over the baseline probability (35\%). Results in column 2 suggest the effect of past-work connections is larger than that of educational connections $(0.221$ versus 0.125 ). The coefficient on DISTANCE is significantly negative as predicted. The coefficients on other control variables are largely insignificant, which may stem from the fact that nonsupplier vendors in our sample are, by design, similar to suppliers.

\subsection{Endogeneity and sensitivity analyses}

Though we include the comprehensive set of control variables described in section 4.1 in the supplier-selection model, given that this process involves multiple unobservable factors, endogeneity concerns such as omitted correlated variables need to be further addressed. In this section, we detail additional analyses we perform to mitigate these concerns.

\subsubsection{The effect of management rank and position}

The effect of personal connections likely varies with the influence of the connected executive on supplier selection and her function in the firm. For example, customer COOs that typically oversee supplier selection in firms are likely to have a stronger influence on the selection process than any other C-level executive. ${ }^{8}$ To the extent that endogeneity exists in our analysis, it is unlikely to vary predictably with the rank and position of the connected executive. Thus the tests of the effect of personal connections across different levels and functions of connected executives can help alleviate the endogeneity concern.

Table 5 reports results of such tests based on the supplier-selection sample. Columns 1-3 focus on executive ranks: CEOs in column 1, C-level executives (e.g., CEO, CFO, and $\mathrm{COO}$ ) in column 2, and lower-level executives in column 3. To make a fair comparison across executive levels or functions, we keep in each analysis only

\footnotetext{
$\overline{7}$ This magnitude is quantitatively and qualitatively similar to the marginal effect (18.9\%) computed from an untabulated probit estimation.

${ }^{8}$ Web searches yield a few articles that provide anecdotal evidence indicating the COO is the officer overseeing the supply chain. See, for example, McCann (2014).
} 
Table 4 Supplier-Selection Regression - The Effect of Personal Connections on Supplier Selection

\begin{tabular}{|c|c|c|c|c|}
\hline & \multicolumn{2}{|c|}{ Connection (YES/NO) } & \multicolumn{2}{|c|}{ Log Number of Connections } \\
\hline & 1 & 2 & 3 & 4 \\
\hline \multirow[t]{2}{*}{ CON_WORK } & & $0.221 * * *$ & & $0.163 * * *$ \\
\hline & & $(5.77)$ & & $(4.79)$ \\
\hline \multirow[t]{2}{*}{$C O N \_E D U$} & & $0.125 * *$ & & $0.150^{* *}$ \\
\hline & & $(2.26)$ & & $(2.28)$ \\
\hline \multirow[t]{2}{*}{ CONNECTED } & $0.210 * * *$ & & $0.173 * * *$ & \\
\hline & $(4.66)$ & & $(4.21)$ & \\
\hline \multirow[t]{2}{*}{ DISTANCE } & $-0.019 * *$ & $-0.018^{* * *}$ & $-0.018 * *$ & $-0.018 * *$ \\
\hline & $(-2.62)$ & $(-2.68)$ & $(-2.52)$ & $(-2.53)$ \\
\hline \multirow{2}{*}{$L A R G E S T \_S$} & 0.021 & 0.025 & 0.022 & 0.024 \\
\hline & $(0.43)$ & $(0.54)$ & $(0.47)$ & $(0.52)$ \\
\hline \multirow[t]{2}{*}{ IVY_LEAGUE_S } & 0.003 & -0.003 & -0.002 & -0.004 \\
\hline & $(0.07)$ & $(-0.08)$ & $(-0.06)$ & $(-0.11)$ \\
\hline \multirow{2}{*}{ PHD_MASTERS_S } & -0.048 & -0.046 & -0.046 & -0.045 \\
\hline & $(-1.16)$ & $(-1.13)$ & $(-1.10)$ & $(-1.08)$ \\
\hline \multirow[t]{2}{*}{$S I Z E \_S$} & 0.004 & 0.003 & 0.003 & 0.003 \\
\hline & $(0.64)$ & $(0.37)$ & $(0.40)$ & $(0.35)$ \\
\hline \multirow[t]{2}{*}{$A G E \_S$} & $-0.050 * * *$ & $-0.050^{* * *}$ & $-0.049 * * *$ & $-0.049 * * *$ \\
\hline & $(-3.15)$ & $(-3.09)$ & $(-3.07)$ & $(-3.06)$ \\
\hline \multirow[t]{2}{*}{$R O A \_S$} & -0.503 & -0.506 & -0.509 & -0.519 \\
\hline & $(-1.08)$ & $(-1.08)$ & $(-1.10)$ & $(-1.11)$ \\
\hline \multirow[t]{2}{*}{$L E V \_S$} & 0.004 & 0.007 & 0.002 & 0.004 \\
\hline & $(0.05)$ & $(0.10)$ & $(0.04)$ & $(0.06)$ \\
\hline \multirow[t]{2}{*}{ TANGIBILITY_S } & 0.056 & 0.051 & 0.047 & 0.046 \\
\hline & $(0.47)$ & $(0.44)$ & $(0.39)$ & $(0.38)$ \\
\hline \multirow[t]{2}{*}{$\mathrm{CASH}{ }_{-} \mathrm{S}$} & 0.004 & 0.005 & 0.001 & 0.002 \\
\hline & $(0.04)$ & $(0.05)$ & $(0.01)$ & $(0.02)$ \\
\hline \multirow[t]{2}{*}{$S A L E \_G R O W T H \_S$} & 0.003 & 0.003 & 0.004 & 0.004 \\
\hline & $(0.17)$ & $(0.21)$ & $(0.24)$ & $(0.26)$ \\
\hline \multirow[t]{2}{*}{$G M \_S$} & $0.109^{* * *}$ & $0.105 * *$ & $0.103 * *$ & $0.102^{* *}$ \\
\hline & $(2.66)$ & $(2.51)$ & $(2.41)$ & $(2.36)$ \\
\hline \multirow[t]{2}{*}{$P M \_S$} & -0.018 & -0.012 & -0.011 & -0.009 \\
\hline & $(-0.25)$ & $(-0.17)$ & $(-0.15)$ & $(-0.13)$ \\
\hline \multirow[t]{2}{*}{ CAPEX_S } & 0.189 & 0.199 & 0.186 & 0.195 \\
\hline & $(0.5)$ & $(0.53)$ & $(0.50)$ & $(0.52)$ \\
\hline \multirow[t]{2}{*}{$D A Y S \_I N V \_S$} & 0.000 & 0.000 & 0.000 & 0.000 \\
\hline & $(0.19)$ & $(0.24)$ & $(0.22)$ & $(0.23)$ \\
\hline \multirow[t]{2}{*}{$D A Y S \_A P \_S$} & 0.000 & 0.000 & 0.000 & 0.000 \\
\hline & $(-0.16)$ & $(-0.20)$ & $(-0.17)$ & $(-0.19)$ \\
\hline \multirow[t]{2}{*}{$D A Y S \_A R \_S$} & 0.000 & 0.000 & 0.000 & 0.000 \\
\hline & $(-0.05)$ & $(0.00)$ & $(-0.06)$ & $(-0.04)$ \\
\hline
\end{tabular}


Table 4 (continued)

\begin{tabular}{lcccc}
\hline & \multicolumn{2}{c}{ Connection (YES/NO) } & \multicolumn{2}{c}{ Log Number of Connections } \\
& \multicolumn{2}{c}{ Log Number of Connections } & & \\
PPE_TO_S & $\mathbf{1}$ & $\mathbf{2}$ & $\mathbf{3}$ & $\mathbf{4}$ \\
& 0.001 & 0.001 & 0.001 & 0.001 \\
IHLDS_S & $(1.52)$ & $(1.53)$ & $(1.52)$ & $(1.52)$ \\
& 0.159 & 0.159 & 0.146 & 0.148 \\
NEGFCF_S & $(0.94)$ & $(0.94)$ & $(0.87)$ & $(0.87)$ \\
& 0.014 & 0.013 & 0.011 & 0.011 \\
RND_S & $(0.42)$ & $(0.41)$ & $(0.36)$ & $(0.34)$ \\
& 0.141 & 0.131 & 0.142 & 0.139 \\
CONSTANT & $(0.86)$ & $(0.80)$ & $(0.85)$ & $(0.83)$ \\
& $0.452^{* * *}$ & $0.443 * * *$ & $0.464 * * *$ & $0.461 * * *$ \\
Customer-Year FE & $(4.43)$ & $(4.33)$ & $(4.56)$ & $(4.55)$ \\
$\mathrm{N}$ & $\mathrm{Y}$ & $\mathrm{Y}$ & $\mathrm{Y}$ & $\mathrm{Y}$ \\
$\mathrm{R}{ }^{2}$ & 4060 & 4060 & 4060 & 4060 \\
& 0.07 & 0.07 & 0.07 & 0.07 \\
\hline
\end{tabular}

This table reports results of testing the effect of personal connections on supplier selection for all customersupplier pairs and customer-nonsupplier vendor pairs $(N=4060)$. Columns $1-2(3-4)$ report results for the personal-connection variable defined as an indicator variable that takes the value of 1 for the existence of at least one personal connection (the natural logarithm of one plus the number of connections) between executives of the customer/vendor pair and 0 otherwise. In columns 1 and 3, the connection variables are constructed to take the value of 1 if either educational connection $\left(C O N_{-} E D U\right)$ or a work-based connection

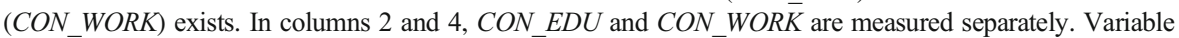
definitions are provided in Appendix Table 10. Customer-year fixe effects are included. Standard errors are clustered by customer and year. Coefficient estimates are reported in the top row, and $t$-statistics are reported in parentheses below. $* * *, * *$, and $*$ denote two-tailed significance at the $0.01,0.05$, and 0.10 levels, respectively.

observations in which the specific personal connection in consideration exists. For example, in column 1, where we focus on CEO-CEO connections, we only include observations in which either customer CEOs are connected to vendor CEOs or no connection exists between the customer and vendor firm at all. In other words, we exclude observations with personal connections through CFOs or COOs and so on. This sample-selection procedure yields different numbers of observations across columns. The coefficient on CONNECTED is positive and significant for all executive ranks. ${ }^{9}$ The magnitude of the coefficient is larger for C-level connections than for nonC-level connections ( 0.371 versus 0.243$)$, with the largest effect coming from the connections between CEOs (0.500). The difference in the coefficient estimates between the $\mathrm{CEO}$ connections and the non-C-level connections is significant at the $1 \%$ level using an F-test. Columns 4-6 focus on customer executives' function. Column 4 reports results for vendor connections (at any level and position) with the customer's CEO; column 5, for vendor connections with the customer's CFO; and column 6, for vendor connections with the customer's COO. The coefficient on CONNECTED is positive and significant across all executive functions. The magnitude of the coefficient

\footnotetext{
$\overline{{ }^{9} \text { Results are similar though weaker }}$ if we keep other connections in the regression.
} 
Table 5 Supplier Selection Regression - The Effect of Personal Connections on the Selection of Suppliers by Executive Ranks and Functions

\begin{tabular}{|c|c|c|c|c|c|c|}
\hline & CEO-CEO & C Level & $\begin{array}{c}\text { Non-C } \\
\text { Level }\end{array}$ & $\begin{array}{r}\text { CUST } \\
\_ \text {CEO }\end{array}$ & $\begin{array}{r}\text { CUST } \\
\_ \text {CFO }\end{array}$ & $\begin{array}{r}\text { CUST } \\
\_ \text {COO }\end{array}$ \\
\hline & 1 & 2 & 3 & 4 & 5 & 6 \\
\hline CONNECTED & $\begin{array}{c}0.500 * * * \\
(3.51)\end{array}$ & $\begin{array}{c}0.371 * * * \\
(4.02)\end{array}$ & $\begin{array}{c}0.243 * * * \\
(4.81)\end{array}$ & $\begin{array}{c}0.302 * * * \\
(3.05)\end{array}$ & $\begin{array}{c}0.234 * * \\
(2.52)\end{array}$ & $\begin{array}{c}0.472 * * * \\
(3.18)\end{array}$ \\
\hline DISTANCE & $\begin{array}{c}-0.028 * * \\
(-2.56)\end{array}$ & $\begin{array}{c}-0.029 * * * \\
(-3.05)\end{array}$ & $\begin{array}{c}-0.019 * * \\
(-2.57)\end{array}$ & $\begin{array}{c}-0.028 * * * \\
(-2.89)\end{array}$ & $\begin{array}{c}-0.030 * * * \\
(-2.86)\end{array}$ & $\begin{array}{c}-0.029 * * * \\
(-2.77)\end{array}$ \\
\hline LARGEST_S & $\begin{array}{l}0.059 \\
(0.73)\end{array}$ & $\begin{array}{l}0.047 \\
(0.55)\end{array}$ & $\begin{array}{l}0.026 \\
(0.44)\end{array}$ & $\begin{array}{l}0.046 \\
(0.65)\end{array}$ & $\begin{array}{l}0.043 \\
(0.56)\end{array}$ & $\begin{array}{l}0.058 \\
(0.71)\end{array}$ \\
\hline$I V Y \_L E A G U E \_S$ & $\begin{array}{l}-0.016 \\
(-0.32)\end{array}$ & $\begin{array}{l}-0.016 \\
(-0.34)\end{array}$ & $\begin{array}{l}0.008 \\
(0.21)\end{array}$ & $\begin{array}{l}-0.011 \\
(-0.22)\end{array}$ & $\begin{array}{l}-0.031 \\
(-0.64)\end{array}$ & $\begin{array}{l}-0.020 \\
(-0.39)\end{array}$ \\
\hline PHD_MASTERS_S & $\begin{array}{l}-0.030 \\
(-0.65)\end{array}$ & $\begin{array}{l}-0.031 \\
(-0.73)\end{array}$ & $\begin{array}{c}-0.040 \\
(-1)\end{array}$ & $\begin{array}{l}-0.034 \\
(-0.79)\end{array}$ & $\begin{array}{l}-0.028 \\
(-0.62)\end{array}$ & $\begin{array}{l}-0.025 \\
(-0.55)\end{array}$ \\
\hline$S I Z E \_S$ & $\begin{array}{l}-0.002 \\
(-0.17)\end{array}$ & $\begin{array}{l}-0.001 \\
(-0.06)\end{array}$ & $\begin{array}{l}0.001 \\
(0.18)\end{array}$ & $\begin{array}{l}-0.004 \\
(-0.34)\end{array}$ & $\begin{array}{l}0.001 \\
(0.15)\end{array}$ & $\begin{array}{l}-0.002 \\
(-0.17)\end{array}$ \\
\hline$A G E \_S$ & $\begin{array}{c}-0.044 * * * \\
(-2.9)\end{array}$ & $\begin{array}{c}-0.045 * * * \\
(-3.15)\end{array}$ & $\begin{array}{c}-0.051 * * * \\
(-3.15)\end{array}$ & $\begin{array}{c}-0.047 * * * \\
(-3.20)\end{array}$ & $\begin{array}{c}-0.043 * * * \\
(-2.93)\end{array}$ & $\begin{array}{c}-0.045 * * * \\
(-3.10)\end{array}$ \\
\hline$R O A \_S$ & $\begin{array}{c}-0.931^{*} \\
(-1.67)\end{array}$ & $\begin{array}{l}-0.892^{*} \\
(-1.67)\end{array}$ & $\begin{array}{l}-0.466 \\
(-0.97)\end{array}$ & $\begin{array}{l}-0.856 \\
(-1.59)\end{array}$ & $\begin{array}{l}-0.917 \\
(-1.60)\end{array}$ & $\begin{array}{c}-0.902 * \\
(-1.65)\end{array}$ \\
\hline$L E V \_S$ & $\begin{array}{l}0.001 \\
(0.01)\end{array}$ & $\begin{array}{l}-0.005 \\
(-0.06)\end{array}$ & $\begin{array}{l}-0.005 \\
(-0.07)\end{array}$ & $\begin{array}{l}-0.004 \\
(-0.04)\end{array}$ & $\begin{array}{l}-0.002 \\
(-0.03)\end{array}$ & $\begin{array}{l}0.019 \\
(0.22)\end{array}$ \\
\hline TANGIBILITY_S & $\begin{array}{l}0.034 \\
(0.22)\end{array}$ & $\begin{array}{l}0.052 \\
(0.35)\end{array}$ & $\begin{array}{l}0.052 \\
(0.41)\end{array}$ & $\begin{array}{l}0.056 \\
(0.41)\end{array}$ & $\begin{array}{l}0.038 \\
(0.25)\end{array}$ & $\begin{array}{l}0.022 \\
(0.15)\end{array}$ \\
\hline$C A S H \_S$ & $\begin{array}{c}-0.023 \\
(-0.2)\end{array}$ & $\begin{array}{l}-0.017 \\
(-0.15)\end{array}$ & $\begin{array}{l}0.013 \\
(0.13)\end{array}$ & $\begin{array}{l}-0.016 \\
(-0.15)\end{array}$ & $\begin{array}{l}-0.016 \\
(-0.13)\end{array}$ & $\begin{array}{l}-0.029 \\
(-0.25)\end{array}$ \\
\hline SALE_GROWTH_S & $\begin{array}{l}0.003 \\
(0.24)\end{array}$ & $\begin{array}{l}0.003 \\
(0.18)\end{array}$ & $\begin{array}{l}0.003 \\
(0.20)\end{array}$ & $\begin{array}{l}0.003 \\
(0.24)\end{array}$ & $\begin{array}{l}0.003 \\
(0.20)\end{array}$ & $\begin{array}{l}0.003 \\
(0.24)\end{array}$ \\
\hline$G M \_S$ & $\begin{array}{c}0.105 * \\
(1.76)\end{array}$ & $\begin{array}{c}0.116^{* *} \\
(2.03)\end{array}$ & $\begin{array}{c}0.096 * * \\
(2.01)\end{array}$ & $\begin{array}{c}0.109 * \\
(1.87)\end{array}$ & $\begin{array}{c}0.112 * \\
(1.95)\end{array}$ & $\begin{array}{c}0.104 * \\
(1.80)\end{array}$ \\
\hline$P M \_S$ & $\begin{array}{l}0.033 \\
(0.33)\end{array}$ & $\begin{array}{l}0.016 \\
(0.17)\end{array}$ & $\begin{array}{l}-0.011 \\
(-0.17)\end{array}$ & $\begin{array}{l}0.021 \\
(0.24)\end{array}$ & $\begin{array}{l}0.027 \\
(0.27)\end{array}$ & $\begin{array}{l}0.036 \\
(0.36)\end{array}$ \\
\hline CAPEX_S & $\begin{array}{l}0.327 \\
(0.82)\end{array}$ & $\begin{array}{l}0.353 \\
(0.96)\end{array}$ & $\begin{array}{l}0.234 \\
(0.59)\end{array}$ & $\begin{array}{l}0.275 \\
(0.72)\end{array}$ & $\begin{array}{l}0.322 \\
(0.84)\end{array}$ & $\begin{array}{l}0.394 \\
(1.01)\end{array}$ \\
\hline$D A Y S \_I N V \_S$ & $\begin{array}{l}0.000 \\
(0.34)\end{array}$ & $\begin{array}{l}0.000 \\
(0.28)\end{array}$ & $\begin{array}{l}0.000 \\
(0.21)\end{array}$ & $\begin{array}{l}0.000 \\
(0.27)\end{array}$ & $\begin{array}{l}0.000 \\
(0.23)\end{array}$ & $\begin{array}{l}0.000 \\
(0.38)\end{array}$ \\
\hline$D A Y S \_A P \_S$ & $\begin{array}{l}0.000 \\
(0.03)\end{array}$ & $\begin{array}{c}0.000 \\
(-0.01)\end{array}$ & $\begin{array}{l}0.000 \\
(0.03)\end{array}$ & $\begin{array}{c}0.000 \\
(-0.10)\end{array}$ & $\begin{array}{c}0.000 \\
(-0.02)\end{array}$ & $\begin{array}{c}0.000 \\
(-0.03)\end{array}$ \\
\hline$D A Y S \_A R \_S$ & $\begin{array}{c}0.000 \\
(-0.08)\end{array}$ & $\begin{array}{c}0.000 \\
(-0.10)\end{array}$ & $\begin{array}{c}0.000 \\
(-0.27)\end{array}$ & $\begin{array}{c}0.000 \\
(-0.09)\end{array}$ & $\begin{array}{c}0.000 \\
(-0.01)\end{array}$ & $\begin{array}{c}0.000 \\
(-0.10)\end{array}$ \\
\hline PPE_TO_S & $\begin{array}{c}0.001 * * \\
(2.31)\end{array}$ & $\begin{array}{c}0.001 * * \\
(2.35)\end{array}$ & $\begin{array}{l}0.001 \\
(1.25)\end{array}$ & $\begin{array}{c}0.001 * * \\
(2.37)\end{array}$ & $\begin{array}{c}0.001 * * \\
(2.49)\end{array}$ & $\begin{array}{c}0.001 * * \\
(2.27)\end{array}$ \\
\hline
\end{tabular}


Table 5 (continued)

\begin{tabular}{|c|c|c|c|c|c|c|}
\hline & СЕО-СЕО & C Level & $\begin{array}{c}\text { Non-C } \\
\text { Level }\end{array}$ & $\begin{array}{r}\text { CUST } \\
\text { _CEO }\end{array}$ & $\begin{array}{l}\text { CUST } \\
\_ \text {CFO }\end{array}$ & $\begin{array}{r}\text { CUST } \\
\text { COO }\end{array}$ \\
\hline & 1 & 2 & 3 & 4 & 5 & 6 \\
\hline \multirow[t]{2}{*}{ IHLDS_S } & 0.205 & 0.222 & 0.197 & 0.23 & 0.234 & 0.208 \\
\hline & $(1.40)$ & $(1.45)$ & $(1.15)$ & (1.59) & $(1.42)$ & (1.31) \\
\hline \multirow[t]{2}{*}{$N E G F C F \_S$} & 0.012 & 0.012 & 0.020 & 0.009 & 0.010 & 0.015 \\
\hline & $(0.31)$ & $(0.32)$ & $(0.58)$ & $(0.25)$ & $(0.24)$ & $(0.38)$ \\
\hline \multirow[t]{2}{*}{$R N D \_S$} & 0.066 & 0.092 & 0.116 & 0.104 & 0.098 & 0.078 \\
\hline & $(0.37)$ & $(0.53)$ & $(0.69)$ & $(0.62)$ & $(0.52)$ & $(0.44)$ \\
\hline \multirow[t]{2}{*}{ CONSTANT } & $0.537 * * *$ & $0.528 * * *$ & $0.466^{* * * *}$ & $0.548 * * *$ & $0.525 * * *$ & $0.544 * * *$ \\
\hline & (3.94) & $(4.03)$ & $(4.30)$ & $(4.50)$ & (4.13) & (4.05) \\
\hline Customer-Year FE & $\mathrm{Y}$ & $\mathrm{Y}$ & $\mathrm{Y}$ & $\mathrm{Y}$ & $\mathrm{Y}$ & $\mathrm{Y}$ \\
\hline $\mathrm{N}$ & 3228 & 3286 & 3834 & 3296 & 3258 & 3238 \\
\hline R2 & 0.11 & 0.11 & 0.08 & 0.10 & 0.10 & 0.11 \\
\hline
\end{tabular}

This table reports results of OLS regressions investigating the differential effect of personal connections based on executive rank and position for all customer-supplier pairs and customer-nonsupplier vendor pairs in the supplier-selection sample $(N=4060)$. We remove all observations with a personal connection not specified in the regression title, which causes the number of observations in each regression to vary. The personalconnection variable (CONNECTED) takes the value of 1 if either an educational connection $(C O N E D U)$ or a past work-based connection $\left(C O N \_W O R K\right)$ exists and 0 otherwise. Column 1 reports results for connections between CEOs. Column 2 reports results for connections between executives at the $\mathrm{C}$ level (e.g., CEO, CFO, and $\mathrm{COO}$ ). Column 3 reports results for connections between executives at the non-C level. Column 4 reports results for connections between customers' CEOs and vendor executives at all rank levels. Column 5 reports results for connections between customers' CFOs and vendor executives at all rank levels. Column 6 reports results for connections between customers' COOs and vendor executives at all rank levels. In each specification, all other types of connected executives are excluded from the analysis. Variable definitions are provided in Appendix Table 10. Customer-year fixed effects are included. Standard errors are clustered by customer and year. Coefficient estimates are reported in the top row, and $t$-statistics are reported in parentheses below. ***, $* *$, and $*$ denote two-tailed significance at the $0.01,0.05$, and 0.10 levels, respectively.

is larger for the COO (0.472) than for the CEO (0.302) or the CFO (0.234), and the differences are statistically significant at the $1 \%$ level using an F-test. Overall, the results in Table 5 comport with our expectations; that is, the effect of personal connections on supplier selection varies with executives rank and position.

\subsubsection{Executive departure analysis}

We identify an exogenous shock to the personal connection-a departure of a connected executive that severs the personal connection between the customer and the supplier - and test whether it affects the duration of the business relationship going forward more than a departure of an unconnected executive. Personal connections between the supply-chain partners facilitate transmission of timely information outside the formal communication channel, alleviating the customer's concerns about supply disruption (e.g., due to the deterioration of suppliers' financial conditions) and moral hazard. However, during the course of the business relations, other employees are likely to develop trust that will reduce the importance of a personal connection in 
mitigating information asymmetries and moral hazards. Thus whether a departure of a connected executive should affect the longevity of supply-chain relations is not clear. Ultimately, whether the newly developed trust can fully substitute for the informal communication channel is an empirical question.

To test the effect of a connected executive departure, we identify all customersupplier pairs that have only one C-level executive departing during the period in which the pair are supply-chain partners. To increase the power of the test and to avoid the confounding effects of multiple departures, we include pairs with only one C-level departure. For example, poor performance of the customer may explain both a high number of customer-executive departures and a termination of a supplier relationship. A single executive departure is less likely due to poor firm performance. The number of C-level departures for the full sample is 3996, and 470 of them are in pairs with a single $\mathrm{C}$-level executive departure. Other data requirements reduce the sample to 308 observations. The unit of analysis is at the executive-customer-supplier level. We use a COX proportional hazard model, specified as follows, to examine whether the supply-chain relationship is shorter following a departure of a connected executive, compared to a departure of an unconnected executive.

$$
\begin{aligned}
H\left(t, D U R A T I O N \_P O S T\right) & =H_{0}(t) *\left(\beta_{0}+\beta_{1} * \text { CONNECTED_EXEC } c_{i, j, q, t}\right. \\
& +\beta_{2} * \text { DISTANCE } E_{i, j, t}+\beta_{3} * D U R A T I O N \_P R E_{i, j, t}+\beta_{4} * \text { CONNECTED_FIRM } M_{i, j, t} \\
& \left.+\beta_{l} * S U P P \_C O N T R O L S_{l, j, t}+\beta_{m} * C U S T \_C O N T R O L S_{m, i, t}+\gamma_{t} * Y E A R \_F E_{t}+\varepsilon_{i, j, t}\right),
\end{aligned}
$$

where DURATION_POST is the time in months starting from executive $q$ 's departure and ending with the termination of the business relation. This variable is right censored for cases in which a supply-chain relationship exists at the end of the sample period. Seventy-eight of the 308 observations are censored. The subscripts $i, j, t, l$, and $m$ index for customer $i$, supplier $j$, year $t$, supplier characteristic $l$, and customer characteristic $m$. CONNECTED_EXEC $C_{i, j, q, t}$ is an indicator variable that takes the value of 1 if the departing executive, $q$, is personally connected to an executive at the counterparty and 0 otherwise. DISTANCE $E_{i, j, t}$ is the natural logarithm of the distance in miles between the zip code of the customer headquarters and that of the supplier headquarters. DURATION_PRE $E_{i, j, t}$ is the duration in months of the supply-chain relationship before the executive departure. We control for the duration before the executive departure, because it may affect the likelihood of termination. CONNECTED_FIRM $M_{i, j, t}$ is an indicator variable that takes the value of 1 if the pair of firms has another personal connection besides the departing executive, $q$, and 0 otherwise. We expect an additional connection to mute the effect of the departure. SUPP_CONTROLS $S_{l, j, t}$ is a set of supplier $j$ 's controls that are largely similar to the supplier-selection analysis. We also include customer size, age, ROA, and stock returns to control for customer $i$ 's performance.

Table 6, Panel A, reports descriptive statistics for the 308 observations used in the analysis, partitioned based on whether the departing C-level executive is personally connected. A little over $5 \%$ of the departing executives are personally connected. The average duration of the customer-supplier relationship prior to the departure of the executive is similar for both connected and unconnected executive departures (10.5 months versus 13.2 months, 
Table 6 Exogenous Shock - Executive Departure Analysis

\begin{tabular}{|c|c|c|c|c|c|c|c|}
\hline \multicolumn{8}{|l|}{ Panel A: Descriptive Statistics } \\
\hline & \multicolumn{3}{|c|}{ Unconnected execs (292) } & \multicolumn{3}{|c|}{ Connected execs (16) } & \multirow[t]{2}{*}{ Diff } \\
\hline & Mean & STD & Median & Mean & STD & Median & \\
\hline DURATION (Months) & 39.62 & 18.28 & 36.00 & 28.50 & 8.63 & 24.00 & $11.116^{* *}$ \\
\hline DURATION_POST(Months) & 26.39 & 12.42 & 23.00 & 18.00 & 4.23 & 17.00 & $8.387 * * *$ \\
\hline DURATION_PRE (Months) & 13.23 & 15.37 & 9.00 & 10.50 & 9.44 & 8.00 & 2.729 \\
\hline DISTANCE $(L N)$ & 6.41 & 1.55 & 6.82 & 5.33 & 2.29 & 5.99 & $1.076^{* * *}$ \\
\hline$S I Z E \_S$ & 5.43 & 1.84 & 5.47 & 6.70 & 1.75 & 6.24 & $-1.266^{* * * *}$ \\
\hline$A G E \_S$ & 2.35 & 0.81 & 2.40 & 2.52 & 0.72 & 2.35 & -0.168 \\
\hline$R O A \_S$ & 0.00 & 0.08 & 0.02 & 0.01 & 0.05 & 0.02 & -0.007 \\
\hline$L E V \_S$ & 0.23 & 0.41 & 0.12 & 0.29 & 0.30 & 0.16 & -0.058 \\
\hline TANGIBILITY_S & 0.23 & 0.24 & 0.13 & 0.24 & 0.28 & 0.08 & -0.008 \\
\hline$C A S H \_S$ & 0.29 & 0.26 & 0.23 & 0.26 & 0.24 & 0.22 & 0.026 \\
\hline SALE_GROWTH_S & 0.26 & 0.66 & 0.12 & 0.05 & 0.36 & 0.10 & 0.212 \\
\hline$G M \_S$ & 0.17 & 1.17 & 0.39 & 0.25 & 0.70 & 0.34 & -0.08 \\
\hline$P M \_S$ & -0.50 & 1.89 & 0.00 & -0.26 & 0.77 & 0.02 & -0.242 \\
\hline$C A P E X \_S$ & 0.06 & 0.08 & 0.03 & 0.05 & 0.06 & 0.02 & 0.015 \\
\hline$D A Y S \_I N V \_S$ & 64.90 & 74.71 & 38.04 & 34.00 & 38.85 & 22.88 & 30.898 \\
\hline$D A Y S_{-} A P \_S$ & 74.37 & 105.33 & 44.06 & 52.98 & 31.05 & 55.53 & 21.392 \\
\hline$D A Y S \_A R \_S$ & 61.19 & 44.56 & 54.80 & 55.86 & 17.94 & 52.25 & 5.328 \\
\hline$P P E \_T O \_S$ & 12.06 & 20.52 & 5.27 & 18.81 & 32.60 & 7.01 & -6.751 \\
\hline IHLDS_S & 0.09 & 0.10 & 0.06 & 0.05 & 0.05 & 0.05 & 0.041 \\
\hline$N E G F C F \_S$ & 0.48 & 0.50 & 0.00 & 0.38 & 0.50 & 0.00 & 0.101 \\
\hline$R N D \_S$ & 0.11 & 0.19 & 0.04 & 0.09 & 0.19 & 0.01 & 0.018 \\
\hline$S I Z E_{-} C$ & 9.45 & 1.88 & 9.77 & 10.14 & 1.36 & 10.55 & -0.687 \\
\hline$A G E \_C$ & 3.24 & 0.78 & 3.54 & 3.53 & 0.58 & 3.83 & -0.285 \\
\hline$R E T_{-} C$ & 0.08 & 0.44 & 0.05 & 0.08 & 0.32 & 0.16 & 0.005 \\
\hline$R O A \_C$ & 0.03 & 0.02 & 0.04 & 0.03 & 0.02 & 0.03 & 0.001 \\
\hline$M K S H \_S$ & 0.03 & 0.10 & 0.00 & 0.05 & 0.08 & 0.01 & -0.019 \\
\hline$A G E \_E X E C$ & 53.95 & 7.78 & 54.00 & 53.81 & 7.42 & 52.00 & 0.136 \\
\hline $\begin{array}{l}\text { PROMOTION/ } \\
\text { RETIREMENT }\end{array}$ & 0.24 & 0.43 & 0.00 & 0.50 & 0.45 & 0.00 & -0.007 \\
\hline
\end{tabular}

Panel B: C-level Executives Leaving the Firm: A Turnover Hazard Model, Cox Regression

$\begin{array}{lccc} & \text { All } & \text { Connected Firms } & \text { Promotion / retirement } \\ \text { CONNECTED_EXEC } & 2.641^{* * *} & 5.661^{* * *} & 12.179 * * * \\ & (4.27) & (3.79) & (2.71) \\ \text { CONNECTED_FIRM } & 1.194 & & 2.109 \\ \text { DURATION_PRE } & (1.00) & & (1.28) \\ \text { DISTANCE } & 1.006 & 1.009 & 1.000 \\ & (0.71) & (0.64) & (-0.01) \\ & 1.064 * & 1.201 * * & 1.320\end{array}$


T. Chen et al.

Table 6 (continued)

\begin{tabular}{|c|c|c|c|}
\hline \multirow[t]{2}{*}{$S I Z E \_S$} & 1.058 & 1.098 & 0.752 \\
\hline & $(1.16)$ & $(0.67)$ & $(-1.05)$ \\
\hline \multirow[t]{2}{*}{$A G E \_S$} & 1.047 & 0.816 & 1.422 \\
\hline & $(0.51)$ & $(-0.60)$ & $(1.17)$ \\
\hline \multirow[t]{2}{*}{$R O A \_S$} & $0.037 * * *$ & 0.025 & 0.356 \\
\hline & $(-2.84)$ & $(-0.72)$ & $(-0.18)$ \\
\hline \multirow[t]{2}{*}{$L E V \_S$} & 1.121 & 2.132 & 0.780 \\
\hline & $(0.78)$ & $(0.68)$ & $(-0.32)$ \\
\hline \multirow[t]{2}{*}{ TANGIBILITY_S } & 1.975 & 0.111 & $0.035^{*}$ \\
\hline & $(1.20)$ & $(-1.35)$ & $(-1.70)$ \\
\hline \multirow[t]{2}{*}{$C A S H \_S$} & 1.006 & 1.146 & 0.134 \\
\hline & $(0.01)$ & $(0.12)$ & $(-0.98)$ \\
\hline \multirow[t]{2}{*}{ SALE_GROWTH_S } & 1.095 & $0.450 * *$ & 0.465 \\
\hline & $(0.81)$ & $(-2.15)$ & $(-0.90)$ \\
\hline \multirow[t]{2}{*}{$G M \_S$} & 1.036 & 0.754 & 0.712 \\
\hline & $(0.33)$ & $(-1.06)$ & $(-0.60)$ \\
\hline \multirow[t]{2}{*}{$P M \_S$} & 0.943 & 0.999 & 1.178 \\
\hline & $(-0.86)$ & $(-0.01)$ & $(0.24)$ \\
\hline \multirow[t]{2}{*}{$C A P E X \_S$} & 0.770 & 1.983 & 2269.686 \\
\hline & $(-0.16)$ & $(0.17)$ & (1.21) \\
\hline \multirow[t]{2}{*}{$D A Y S \_I N V \_S$} & 1.000 & 0.999 & 0.999 \\
\hline & $(0.33)$ & $(-0.23)$ & $(-0.19)$ \\
\hline \multirow[t]{2}{*}{$D A Y S \_A P \_S$} & 0.999 & $1.005^{* *}$ & 1.001 \\
\hline & $(-1.14)$ & $(2.16)$ & $(0.45)$ \\
\hline \multirow[t]{2}{*}{$D A Y S \_A R \_S$} & 0.998 & 0.997 & 0.994 \\
\hline & $(-1.31)$ & $(-0.92)$ & $(-0.51)$ \\
\hline \multirow[t]{2}{*}{$P P E \_T O \_S$} & 1.006 & 1.007 & 0.973 \\
\hline & $(1.59)$ & $(1.00)$ & $(-1.22)$ \\
\hline \multirow[t]{2}{*}{$I H L D S \_S$} & $0.115^{* *}$ & 0.004 & 0.011 \\
\hline & $(-2.26)$ & $(-0.83)$ & $(-1.08)$ \\
\hline$N E G F C F \_S$ & 1.100 & 1.099 & 1.338 \\
\hline
\end{tabular}


Table 6 (continued)

\begin{tabular}{lccc}
\hline & All & Connected Firms & Promotion / retirement \\
& $(0.56)$ & $(0.27)$ & $(0.34)$ \\
$R N D \_S$ & 0.984 & 0.336 & $16.661^{*}$ \\
& $(-0.02)$ & $(-0.92)$ & $(1.65)$ \\
MKSH_S & 1.058 & 21.366 & 126.007 \\
& $(0.05)$ & $(1.52)$ & $(1.17)$ \\
SIZE_C & 1.053 & $1.435^{*}$ & 1.019 \\
& $(1.23)$ & $(1.82)$ & $(0.15)$ \\
AGE_C & $0.822^{*}$ & $0.358^{* *}$ & 0.841 \\
& $(-1.83)$ & $(-2.56)$ & $(-0.44)$ \\
RET_C & 0.835 & 1.325 & $0.211^{* * *}$ \\
& $(-0.94)$ & $(0.87)$ & $(-2.73)$ \\
ROA_C & 10.768 & 3.030 & 0.000 \\
& $(0.74)$ & $(0.22)$ & $(-1.04)$ \\
Year FE & $\mathrm{Y}$ & $\mathrm{Y}$ & $\mathrm{Y}$ \\
$\mathrm{N}$ & 308 & 86 & 75 \\
Pseudo-R & 0.04 & 0.12 & 0.12 \\
\hline
\end{tabular}

This table reports results for an analysis testing the effect of a departure of a personally connected executive on the post-departure length of the customer-supplier relationship compared to a departure of an unconnected executive. The sample consists of customer-supplier pairs that experienced one executive departure at the $\mathrm{C}$ level over the sample period $(N=308)$. Panel A reports descriptive statistics on the variable of interest and control variables for the analysis for a sample partitioned by whether the departing $\mathrm{C}$-level executive is personally connected. Panel B reports the estimation of a Cox proportional hazard model, where $h(T)$ is the instantaneous risk of a cease of a supply-chain relationship at time $T$ given the supply-chain relationship survives to time $T$. All supply-chain relationships that continue to exist at the end of the sample period are censored. The dependent variable is computed as the number of months between the executive turnover and the end of the supply-chain relationship (DURATION_POST). The personal-connection variable (CONNECTED_EXEC) is measured as a binary variable valued at 1 if the executive leaving the firm has personal connections with executives at the opposite firm along the supply chain and 0 otherwise. Column 1 reports results for full executive departure sample $(N=308)$. Column 2 reports results for the sample restricted to pairs that have at least one personal connection between them $(N=86)$. Column 3 reports results for an analysis in which we restrict the sample for executive departures only to promotion (departing executive moved to a firm of the same or larger size and assumed a similar or a higher role) or to retirement (departing executive is over 65 years old) $(N=75)$. Variable definitions are provided in Appendix Table 10. Year fixed effects are included. Standard errors are clustered by customer. Hazard ratios are reported in the first row and $z$-statistics are reported in parentheses. $* * *, * *$, and * denote significance at the $.01, .05$, and .10 levels, respectively.

respectively). However, the post-departure duration exhibits a significant difference18 months for the connected executive departure versus 26.4 months for the departure of an unconnected executive. (The difference is significant at the $1 \%$ level.) This comparison serves as initial evidence that the departure of a personally connected executive increases the likelihood of the business relationship being severed.

The evidence is further confirmed in Panel B, in which we report results for the COX hazard model. Based on the hazard ratios reported in column 1, using the sample of all customer-supplier pairs that experienced one C-Level executive departure after the initiation of the relations (308 observations), the departure of a connected C-level 
executive increases the hazard of terminating the supply-chain relationship 2.64 times, relative to an unconnected executive departure.

In column 2 of Table 6, we restrict the departure sample to only connected customersupplier pairs. We do so to address the concern that a connected supply-chain relationship may differ fundamentally from an unconnected one. This restriction reduces our sample to 86 customer-supplier pairs. Results reported in column 2 convey a similar message - that a departure of a connected executive precipitates the end of the business relations more often than a departure of an unconnected executive. In a further effort to verify that the departures are truly exogenous, that is, unrelated to poor firm performance, we keep in the sample in column 3 only departures that are likely due to promotion (the departing executive moved to a similar sized or larger firm at the same role or was promoted to CEO) or retirement (the departing executive is older than 65 years). This restriction reduces our sample to 75 customer-supplier pairs. Results are again similar to that in column 1. Taken together, the results in Table 6 suggest that a loss of personal connections between supply-chain partners precipitates the termination of their supply-chain relation. This evidence not only further supports our hypothesis but also alleviates concerns of endogeneity related to personal connections.

\subsection{Do personal connections mitigate information asymmetries in supplier selection?}

To further strengthen our argument that mitigating information asymmetry between potential trading partners is the channel through which personal connections affect supplier selection, we conduct cross-sectional analyses that vary the degree of information asymmetry. Specifically, we estimate regression model (1) including an interaction variable between the personal-connection variable (CONNECTED) and measures of information asymmetry. We use two measures. The first is the distance between a customer-vendor pair (DISTANCE). Research finds evidence that proximity to suppliers reduces information asymmetry, because of lower costs of communicating soft information, monitoring, or both (Noordewier et al. 1990; Cannon and Cannon and Homburg 2001; Hortacsu et al. 2009; Costello 2013). The second measure is the vendor's accounting quality (ABN_ACCRUALS_S). Financial information represents one important source of hard information. High accounting quality can mitigate information asymmetry between the firm and outsiders (Wittenberg-Moerman 2008; Ball et al. 2008; Beatty et al. 2010; Chen et al. 2015). Financial information allows customers to assess the default risk of a supplier, which is critical to customers' procurement decisions (Babich et al. 2007; Beil 2010). As do Aboody et al. (2005), we measure accounting quality as the abnormal accruals - the absolute value of the residual from the modified Jones model (Dechow et al.1995). Higher abnormal accruals correspond to lower accounting quality and thus to higher information asymmetry.

Table 7 reports results that are based on our baseline sample of 4060 observations. The main effect of information asymmetry is negative and significant for distance and is negative but not statistically significant for abnormal accruals. Consistent with our expectation, the interaction between the information-asymmetry proxy and personal connections is positive and significant for both measures. Economically, a one standard-deviation increase in distance (1.522) is associated with a $68 \%$ increase in the effect of personal connections $(0.025 * 1.522 / 0.056)$. One standard deviation of abnormal accruals (0.186) translates into a $43 \%$ increase in the effect of personal 
Table 7 Supplier-Selection Regression - Cross-Sectional Test: Personal Connections Mitigating Information Asymmetries between Suppliers and Vendors

\begin{tabular}{|c|c|c|}
\hline & $\begin{array}{c}\text { DISTANCE } \\
\text { (1) }\end{array}$ & $\begin{array}{c}\text { ABN_ACCRUALS_S } \\
\text { (2) }\end{array}$ \\
\hline \multirow[t]{2}{*}{ CONNECTED } & 0.056 & $0.158^{* *}$ \\
\hline & $(0.98)$ & $(2.34)$ \\
\hline \multirow[t]{2}{*}{$I A_{-} P R O X Y$} & $-0.026^{* * *}$ & -0.130 \\
\hline & $(-2.73)$ & $(-1.52)$ \\
\hline$I A \_P R O X Y^{*}$ & $0.025^{* *}$ & $0.364 * *$ \\
\hline CONNECTED & $(2.32)$ & $(2.10)$ \\
\hline \multirow[t]{2}{*}{ DISTANCE } & & $-0.020 * *$ \\
\hline & & $(-2.41)$ \\
\hline \multirow[t]{2}{*}{$L A R G E S T \_S$} & 0.022 & 0.021 \\
\hline & $(0.46)$ & $(0.37)$ \\
\hline \multirow[t]{2}{*}{$I V Y \_L E A G U E \_S$} & 0.004 & -0.023 \\
\hline & $(0.10)$ & $(-0.54)$ \\
\hline \multirow[t]{2}{*}{ PHD_MASTERS_S } & -0.048 & -0.046 \\
\hline & $(-1.18)$ & $(-1.36)$ \\
\hline \multirow[t]{2}{*}{$S I Z E \_S$} & 0.005 & 0.003 \\
\hline & $(0.74)$ & $(0.36)$ \\
\hline \multirow[t]{2}{*}{$A G E \_S$} & $-0.051 * * *$ & $-0.042 * *$ \\
\hline & $(-3.16)$ & $(-1.96)$ \\
\hline \multirow[t]{2}{*}{$R O A \_S$} & -0.504 & -0.580 \\
\hline & $(-1.06)$ & $(-1.08)$ \\
\hline \multirow[t]{2}{*}{$L E V \_S$} & 0.004 & 0.045 \\
\hline & $(0.06)$ & $(0.62)$ \\
\hline \multirow[t]{2}{*}{ TANGIBILITY_S } & 0.053 & -0.015 \\
\hline & $(0.45)$ & $(-0.11)$ \\
\hline \multirow[t]{2}{*}{$C A S H \_S$} & 0.005 & 0.023 \\
\hline & $(0.05)$ & $(0.22)$ \\
\hline \multirow[t]{2}{*}{ SALE_GROWTH_S } & 0.003 & 0.014 \\
\hline & $(0.16)$ & $(0.81)$ \\
\hline \multirow[t]{2}{*}{$G M \_S$} & $0.110^{* * * *}$ & $0.118 * *$ \\
\hline & $(2.69)$ & $(2.32)$ \\
\hline \multirow[t]{2}{*}{$P M \_S$} & -0.02 & -0.013 \\
\hline & $(-0.28)$ & $(-0.16)$ \\
\hline \multirow[t]{2}{*}{$C A P E X \_S$} & 0.194 & 0.230 \\
\hline & $(0.52)$ & $(0.64)$ \\
\hline \multirow[t]{2}{*}{$D A Y S \_I N V \_S$} & 0.000 & 0.000 \\
\hline & $(0.19)$ & $(-1.02)$ \\
\hline \multirow[t]{2}{*}{$D A Y S \_A P \_S$} & 0.000 & 0.000 \\
\hline & $(-0.13)$ & $(0.32)$ \\
\hline \multirow[t]{2}{*}{$D A Y S \_A R \_S$} & 0.000 & 0.000 \\
\hline & $(-0.06)$ & $(-0.07)$ \\
\hline
\end{tabular}


Table 7 (continued)

\section{DISTANCE}

(1)

PPE_TO_S

IHLDS_S

NEGFCF_S

$R N D \_S$

CONSTANT

Customer-Year FE

$\mathrm{N}$

$\mathrm{R}^{2}$
0.001

0.013

0.145

$0.490 * * *$

$\mathrm{Y}$

4060

0.07
ABN_ACCRUALS_S

0.000

$0.460 * * *$

$\mathrm{Y}$

3637

0.08

This table reports results of OLS regressions of the relationship between information asymmetry and the effect of personal connections on the likelihood that a vendor becomes a supplier for all customer-supplier pairs and customer-nonsupplier vendor pairs. The dependent variable in both regressions is an indicator variable that takes the value of 1 if the vendor is a supplier and 0 otherwise. The personal-connection variable $(C O N$ $N E C T E D)$ takes the value of 1 if either an educational connection (CON_EDU) or a past work-based connection (CON_WORK) exists and 0 otherwise. IA_PROXY denotes an "information asymmetry proxy." In column 1 ( $N=\overline{40} 60$ as in the supplier-selection sample), the natural logarithm of distance between a vendor and the customer (DISTANCE) serves as the measure of information asymmetry. In column $2(N=3637$ due to the requirement of data to calculate abnormal accruals), abnormal accruals ( $A B N \_$ACCRUALS S ) serves as the measure of information asymmetry. Variable definitions are provided in Appendix Table 10. Customer-year fixed effects are included. Standard errors are clustered by customer and year. Coefficient estimates are reported in the top row, and $t$-statistics are reported in parentheses below. ***, **, and * denote two-tailed significance at the $0.01,0.05$, and 0.10 levels, respectively.

connections $(=0.364 * 0.186 / 0.158)$. These results suggest the importance of personal connections to supplier selection increases with information asymmetry.

\subsection{Consequences of personal connections in the supply chain}

In the next set of analyses, we investigate the consequences of the existence of personal connections between the customer and supplier. The motivation for the subsequent tests is to better depict the effects of personal connections in the supply chain.

\subsubsection{The effect of personal connections on provisions in procurement contracts}

Contractual terms in procurement contracts, such as product warranties, the customer's right to inspect the supplier's plants, supplier-paid liability or property insurance, and pre-scheduled periodic meetings between the two parties, are commonly used to address counterparty risk stemming from adverse selection and moral-hazard problems due to asymmetric information. Hasija et al. (2008) suggest that, when firms face high levels of information asymmetry, the contract documents are longer and more complex to help mitigate the risks associated with uncertainty and ambiguity. Costello (2013) finds contract duration 
decreases with information asymmetry between customers and suppliers and that covenants are more restrictive when the cost of monitoring is high. Contractual provisions, however, are costly to implement, and their enforcement requires effort, time, and, in some cases, payments to third parties. If personal connections mitigate information asymmetries, we expect customers to impose fewer restrictions on connected suppliers. In addition, we predict that contract duration increases with personal connections (Costello 2013).

We use the 10-K wizard tool and start with a broad search for all material contracts in the SEC filings during our sample period that have one of the following terms in the title: "supply contract," "supply agreement," "procurement contract," "procurement agreement," "service(s) contract," or "service(s) agreement." This search yields 6899 hits. We then merge the file with the BoardEx data file, which reduces the sample to 3135 contracts. For the remaining contracts, we first match counterparty names from the contracts with BoardEx data. We eliminate contracts that amend an earlier contract. Firms often redact commercially sensitive information, such as contract duration (Verrecchia and Weber 2006). We exclude these contracts from the analysis, thus reducing the sample to 154 unique contracts. We read each of these contracts and extract data on duration and whether the contract includes particular restrictive provisions.

We investigate the effect of personal connections on provisions in procurement contracts along three dimensions: overall restrictiveness of the contract to the supplier, the inclusion of individual restrictive provisions, and the contract duration. For the overall restrictiveness of the contract, we estimate the following regression model.

$$
\begin{aligned}
& \operatorname{RESTRICTIVENESS}_{i, j, t}=\beta_{0}+\beta_{1} * \operatorname{CONNECTED~}_{i, j, t}+\beta_{2} * \operatorname{DURATION}_{i, j, t} \\
& +\beta_{3} * \text { DISTANCE } E_{i, j, t}+\beta_{4} * E_{\text {EXLUSIVITY }}{ }_{i, j, t} \\
& +\beta_{l} * S U P P \_C O N T R O L S_{l, j, t} \\
& +\beta_{m} * \text { CUST_CONTROLS } S_{m, i, t}+\delta_{t} * Y E A R \_F E_{t} \\
& +\gamma_{k} * I N D \_F E_{k}+\varepsilon_{i, j, t},
\end{aligned}
$$

where RESTRICTIVENESS $S_{i, j, t}$ is an index of procurement contracts' restrictiveness. The subscripts $i, j, t, l$, and $m$ index for customer $i$, supplier $j$, year $t$, supplier characteristic $l$, and customer characteristic $m$. The variable is computed as the number of provisions in each contract that impose a cost or penalty on the supplier. The provisions include product warranty (WARRANTY), supplier-paid liability or property insurance (INSUR$A N C E$ ), right to inspect the supplier's production facilities (INSPECTION), prespecified meetings between the parties (MEETING), third-party certification of the deliverables, and third-party performance guarantee. ${ }^{10}$ The maximum value of the index is six, and the minimum value is zero. Higher values indicate more restrictive contracts. We follow Costello (2013) and control for several factors relating to contract design. The first is duration $\left(D U R A T I O N_{i, j, t}\right)$, which we measure as the shortest possible length in years allowed by the contract. We also control for whether the contract includes an exclusivity term (EXCLUSIVITY $Y_{i, j, t}$ ), which makes seeking alternative suppliers harder, as well as the supplier's size, profitability, leverage, asset tangibility, and Altman Z-score $\left(S U P P \_C O N T R O L S_{l, j, t}\right)$. For

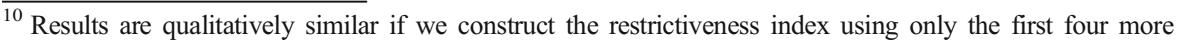
commonly used provisions.
} 
CUST_CONTROLS $S_{m, i, t}$, we include the customer's size. We include year fixed effects and supplier industry fixed effects to control for time-trend and time-invariant differences in acceptable industry contractual terms. ${ }^{11}$

For contract duration as well as for the individual restrictive provisions, we estimate the following regression models.

$$
\begin{aligned}
& \text { DURATION }_{i, j, t}= \beta_{0}+\beta_{1} * \text { CONNECTED }_{i, j, t}+\beta_{2} * \operatorname{DISTANCE}_{i, j, t} \\
&+\beta_{3-6} * \text { PROV }_{k, i, j, t}+\beta_{7} * \text { EXCLUSIVITY }_{i, j, t} \\
&+\beta_{l} * \text { SUPP_CONTROLS }_{l, i, t}+\beta_{m} * \text { CUST_CONTROLS } \\
& m, i, t \\
&+\delta_{t} * \text { YEAR_FE } E_{t}+\gamma_{k} * I N D \_F E_{k}+\varepsilon_{i, j, t},
\end{aligned}
$$

$$
\begin{aligned}
& \operatorname{Prob}\left(\operatorname{PROV}_{k, i, j, t}\right)=\beta_{0}+\beta_{1} * \operatorname{CONNECTED}_{i, j, t}+\beta_{2} * \operatorname{DISTANCE}_{i, j, t} \\
& +\beta_{3} * \text { DURATION }{ }_{i, j, t}+\beta_{4-6} * \text { OTHER_PROV } V_{g, i, j, t} \\
& +\beta_{7} * \text { EXCLUSIVITY }{ }_{i, j, t}+\beta_{l} * S U P P_{-} C_{\text {CONTROLS }}{ }_{l, i, t} \\
& +\beta_{m} * \text { CUST_CONTROLS } S_{m, i, t}+\delta_{t} * Y E A R \_F E_{t} \\
& +\gamma_{k} * I N D \ldots E_{k}+\varepsilon_{i, j, t},
\end{aligned}
$$

where $P R O V_{k, i, j, t}$ refers to one of the first four contract provisions $(k=1$ to 4$)$ consisting of product warranty, supplier-paid liability insurance, inspection right, and prescheduled meetings. Following Costello (2013), we include the other three contractual provisions as control variables when they don't serve as the dependent variable $\left(O T H E R \_P R O V_{g, i, j, t}\right.$, where $\left.g \neq k\right)$. Because these contract terms are likely jointly determined and because coming up with multiple exogenous instruments to jointly estimate all contractual terms is empirically prohibitive, we follow Costello (2013) and use OLS to estimate the regression in eq. (4) and the four regressions of eq. (5) in a system of five seemingly unrelated equations. ${ }^{12}$

Table 8, Panel A, reports descriptive statistics for the sample of 154 procurement contracts. Overall, $43(27 \%)$ contracts involve connected supply-chain parties, which is slightly higher than the sample mean of $21 \%$ reported in Table 2 . On average, a procurement contract lasts 44 months and includes an average of 2.55 provisions restricting the supplier. Contracts with personal connections between a customer's and supplier's executives are, on average, longer (48 months versus 42 months) and less restrictive to the supplier (2.35 versus 2.63 restrictive provisions) than those with no connections. Table 8 , Panel $\mathrm{B}$, reports regression results. Column 1 reports results where the dependent variable is the restrictiveness index, composed of all six provisions. The coefficient on personal connections is negative and

\footnotetext{
${ }^{11}$ We did not include customer fixed effects, because few customers have multiple procurement contracts in our sample. Out of 154 customers, 120 have a single procurement contract, and 12 have two or more contracts. 12 To address the concern that personal connections may affect both the likelihood of entering the procurement-contract sample and the contract design, we endogenize the supplier-selection process by using the Heckman two-step approach. Results are intact and are reported in the online appendix (Table A10).
} 


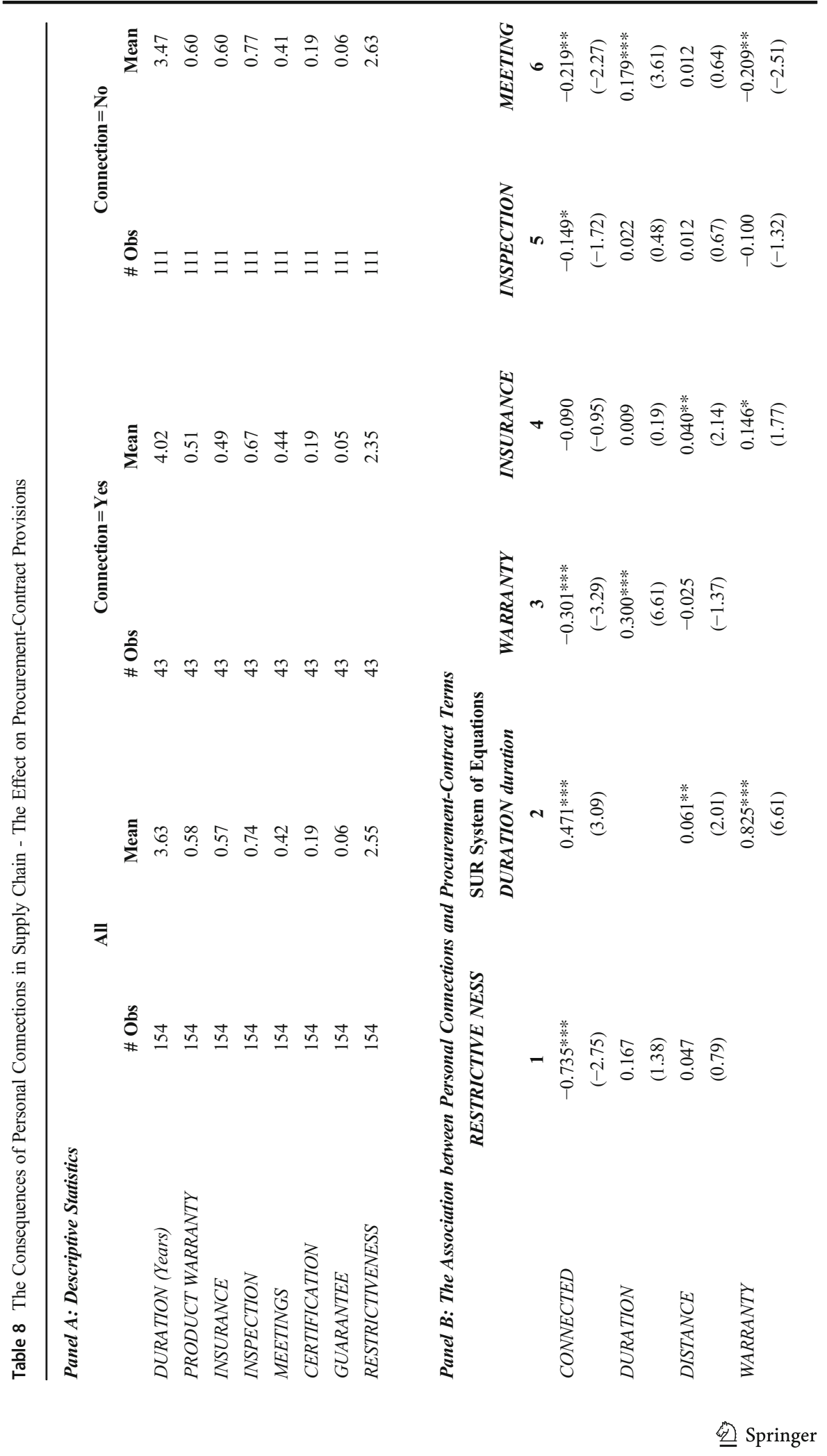




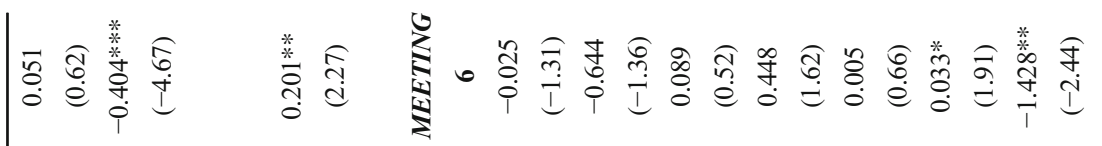

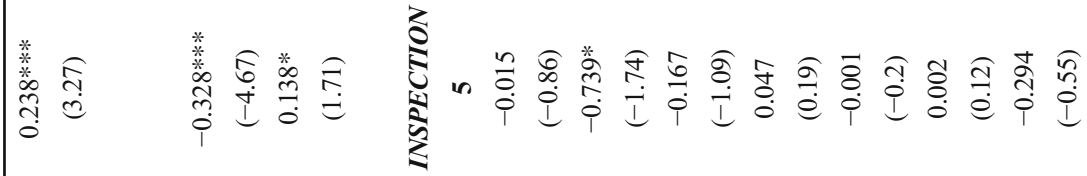

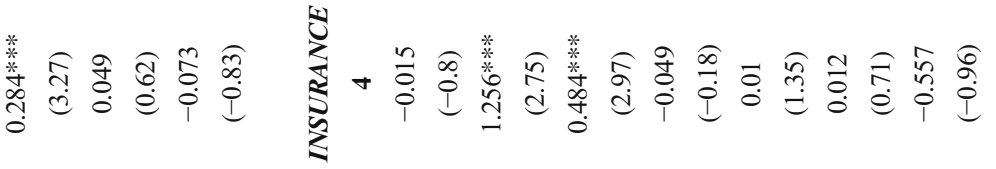

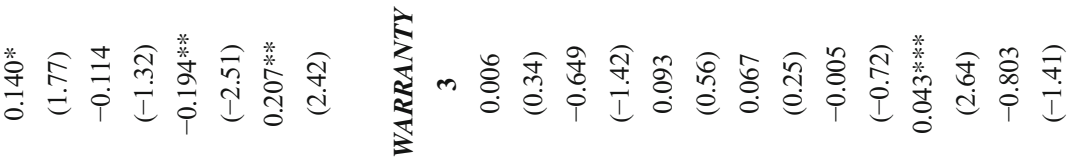

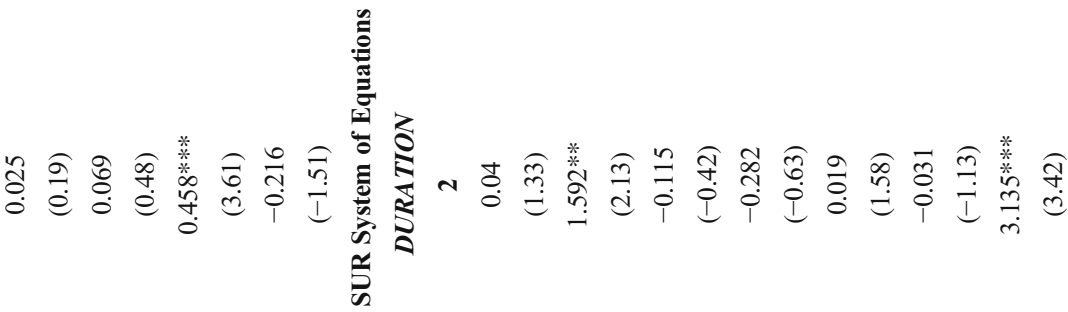

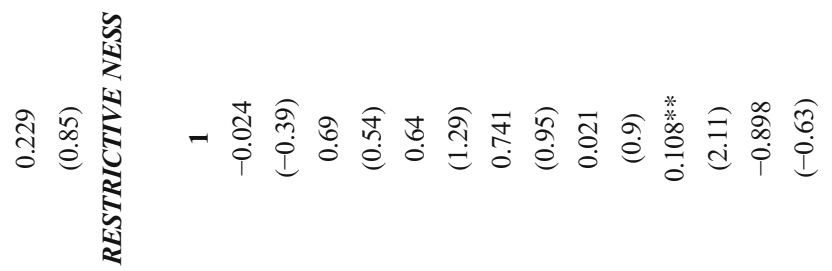

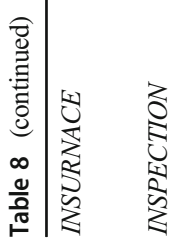

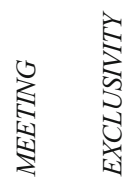

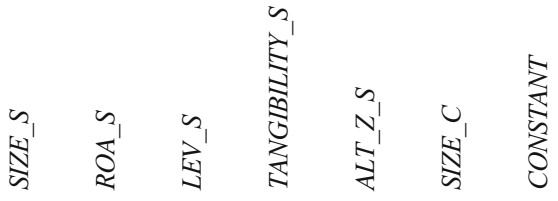




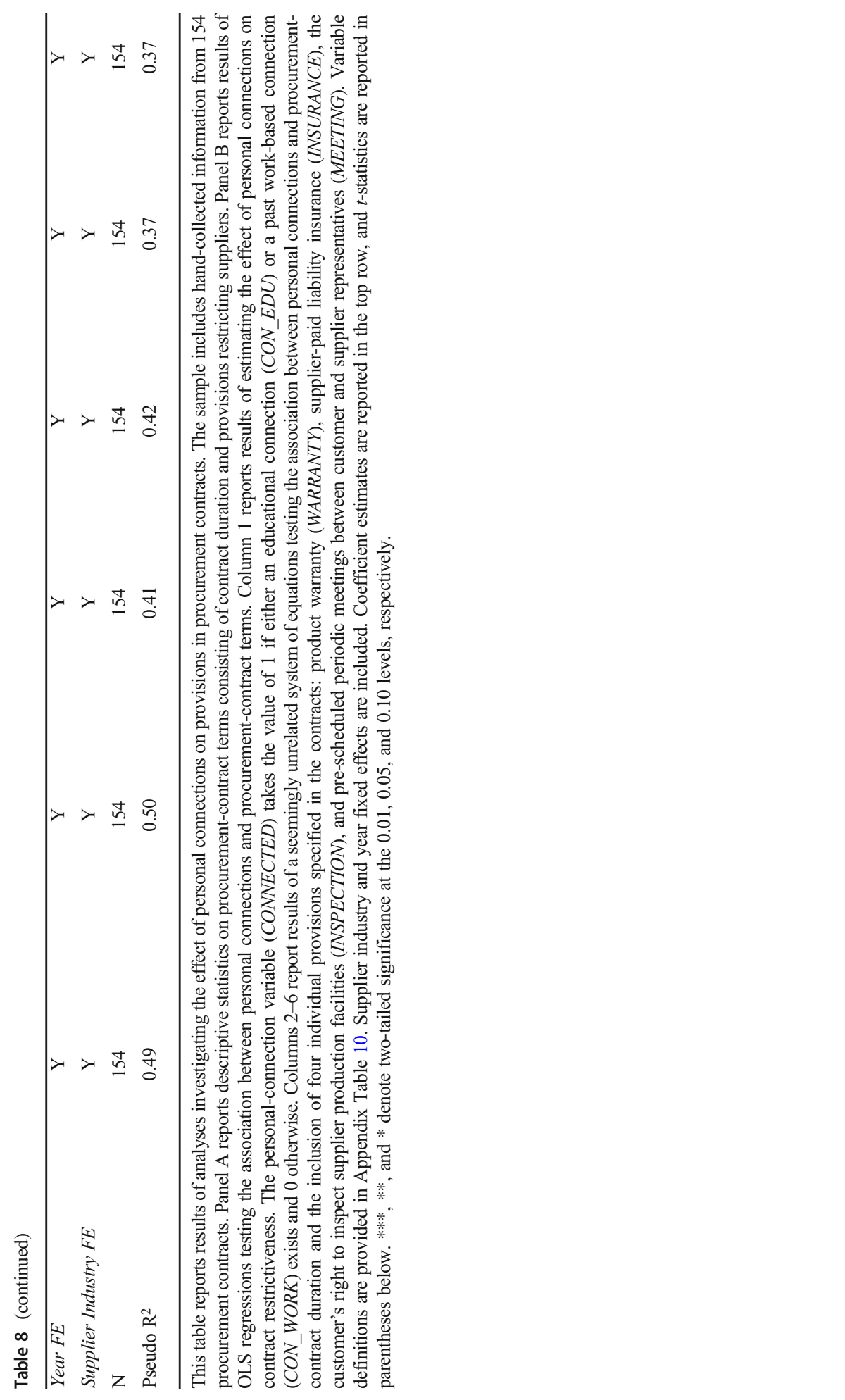


significant at the $1 \%$ level, consistent with our prediction. From an economic perspective, the existence of personal connections reduces the restrictiveness by 0.74 . This amount is economically significant relative to the sample mean of 2.55 .

Columns 2-6 report results of a seemingly unrelated system of eqs. (4) and (5). Columns 2-6 report results for contract duration, requirements of product warranty, supplier-paid liability insurance, the customer's right to inspect the supplier's production facilities, and the provision for pre-scheduled meetings, respectively. Estimation results suggest personal connections increase contract duration by 0.47 of a year, or almost six months, while decreasing the likelihood of all but supplier-paid insurance restrictions to be included in the procurement contract. To the extent that contract restrictiveness increases while contract duration decreases with information asymmetries of the suppliers (Costello 2013), our findings further corroborate the results of supplier-selection analyses, suggesting personal connections can mitigate adverse selection and moral hazard in the supply-chain relationship.

\subsubsection{The effect of personal connections on customer operations}

To further probe the consequences of doing business with personally connected suppliers, we examine whether customer-supplier relationships that were likely created via personal connections affect customer operating efficiency following the formation of the business relationship. We use four alternative measures of operating efficiency: (1) volatility of inventory (INV_STD_C), (2) volatility of cost of goods sold (COGS_STD_C), (3) sales efficiency (SALE_ASSET_C), and (4) return on assets $\left(R O A \_C\right)$. The first two proxies measure the efficiency of inventory management, which likely captures supply-chain efficiency directly. If personal connections mitigate information asymmetry and improve the effectiveness of monitoring suppliers, as we document in sections 4.3 and 4.4.1, fewer disruptions of raw-material supply will occur, implying a lower volatility of inventory after the start of a connected supplychain relationship. In addition, fewer disruptions are likely to translate into not only less fluctuation in product costs but also less inventory hoarding, implying a lower likelihood of write-downs. This argument predicts the volatility of the cost of goods sold falls after the commencement of a connected supply-chain relationship. The third and fourth proxies measure the overall firm efficiency, which may be indirectly affected by the supply chain.

We restrict the sample to actual customer-supplier pairs and run an event study focusing on the fiscal year in which the supply-chain relationship starts, as follows.

$$
\begin{aligned}
& \text { OUTCOME_C } C_{i, j, t}=\beta_{0}+\beta_{1} * \text { CONNECTED }_{i, j, t}+\beta_{2} * P O S T_{i, j, t} \\
& +\beta_{3} * \operatorname{CONNECTED}_{i, j, t} * \mathrm{POST}_{i, j, t}+\beta_{4} * \text { DISTANCE } E_{i, j, t} \\
& +\beta_{5} * \text { DISTANCE } E_{i, j, t} * P_{\text {OST }} i_{i, j}+\beta_{6} * B M_{-} C_{i, t} \\
& +\beta_{7} * L E V C_{i, t}+\beta_{8} * S I Z E_{-} C_{i, t}+\beta_{7} * T A N G I B I L I T Y \_C_{i, t} \\
& +\beta_{9} * A G E_{-} C_{i, t}+\beta_{10} * G M_{-} C_{i, t}+\gamma_{i}^{*} \text { CUSTOMER_FE } E_{i} \\
& +\delta_{t} * \text { YEAR-INDUSTRY FE } E_{t}+\varepsilon_{i, j, t}
\end{aligned}
$$

where $O U T C O M E \_C_{i, j, t}$ takes on the four operating efficiency measures, alternatively. 
Table 9 The Consequences of Personal Connections in Supply Chain - The Effect on Customer's Operations

\begin{tabular}{lcccc}
\hline Panel A: Descriptive Statistics & & & & \\
& N* & Mean & STD & Median \\
DEPENDENT & & & & 0.083 \\
INV_STD_C & 16,885 & 0.125 & 0.126 & 0.028 \\
COGS_STD_C & 18,795 & 0.075 & 0.212 & 0.902 \\
SALE_ASSET_C & 18,619 & 1.104 & 0.761 & 0.126 \\
ROA_C & 18,796 & 0.120 & 0.106 & 0.390 \\
EXPLANATORY & & & & 0.221 \\
BTM_C & 18,804 & 0.447 & 0.757 & 8.128 \\
LEV_C & 18,804 & 0.238 & 0.189 & 0.230 \\
SIZE_C & 18,804 & 8.229 & 1.811 & 3.045 \\
TANGIBILITY_C & 18,804 & 0.306 & 0.240 & 0.337 \\
AGE_C & 18,804 & 3.028 & 0.823 & 0.000 \\
GM_C & 18,804 & 0.366 & 0.247 & 0.380 \\
CONNECTED & 18,804 & 0.175 & &
\end{tabular}

* Number of observations before weighting

Panel B: The Association between Personal Connections and Customer Performance after the Formation of Supply-Chain Relationships

\begin{tabular}{|c|c|c|c|c|}
\hline & INV_STD_C & COGS_STD_C & SALE_ASSET_C & ROA_C \\
\hline \multirow[t]{2}{*}{ CONNECTED } & 0.008 & 0.009 & -0.014 & -0.001 \\
\hline & $(1.60)$ & $(1.41)$ & $(-1.41)$ & $(-0.54)$ \\
\hline \multirow[t]{2}{*}{ POST } & -0.012 & -0.002 & 0.000 & 0.005 \\
\hline & $(-1.24)$ & $(-0.14)$ & $(0.02)$ & $(1.05)$ \\
\hline \multirow[t]{2}{*}{ DISTANCE } & 0.000 & 0.000 & 0.000 & 0.000 \\
\hline & $(0.02)$ & $(-0.24)$ & $(-0.08)$ & $(0.04)$ \\
\hline \multirow[t]{2}{*}{ DISTANCE*POST } & 0.002 & 0.001 & -0.001 & -0.001 \\
\hline & $(1.29)$ & $(0.71)$ & $(-0.18)$ & $(-1.25)$ \\
\hline \multirow[t]{2}{*}{ CONNECTED*POST } & $-0.018^{* * *}$ & $-0.016^{*}$ & $0.025^{*}$ & $0.007^{*}$ \\
\hline & $(-2.65)$ & $(-1.88)$ & $(1.90)$ & (1.89) \\
\hline \multirow[t]{2}{*}{$B T M \_C$} & 0.002 & 0.001 & $-0.026^{* * *}$ & $-0.005^{* * * *}$ \\
\hline & $(1.05)$ & $(0.37)$ & $(-6.67)$ & $(-5.01)$ \\
\hline \multirow[t]{2}{*}{$L E V \_C$} & 0.003 & $0.051 * * *$ & $-0.31 * * *$ & $-0.111^{* * *}$ \\
\hline & $(0.21)$ & $(3.02)$ & $(-12.12)$ & $(-15.76)$ \\
\hline \multirow[t]{2}{*}{$S I Z E_{-} C$} & $-0.008 * *$ & 0.006 & $-0.196^{* * *}$ & $0.006^{* * * *}$ \\
\hline & $(-2.02)$ & (1.29) & $(-26.74)$ & $(3.05)$ \\
\hline \multirow[t]{3}{*}{ TANGIBILITY_C } & $-0.148^{* * *}$ & -0.039 & $0.212 * * *$ & $0.024^{*}$ \\
\hline & $(-5.78)$ & $(-1.27)$ & $(4.53)$ & $(1.85)$ \\
\hline & INV_STD_C & COGS_STD_C & SALE_ASSET_C & ROA_C \\
\hline \multirow[t]{2}{*}{$A G E \_C$} & $-0.076^{* * *}$ & $-0.045^{* * *}$ & $0.176^{* * *}$ & $0.025 * * *$ \\
\hline & $(-6.49)$ & $(-3.36)$ & $(8.52)$ & $(4.35)$ \\
\hline$G M \_C$ & $-0.067 * * *$ & $-0.349 * * *$ & $-0.082 * * *$ & $0.166^{* * * *}$ \\
\hline
\end{tabular}


Table 9 (continued)

\begin{tabular}{lcccc}
\hline & $(-4.46)$ & $(-22.37)$ & $(-3.43)$ & $(25.79)$ \\
CONSTANT & $0.429 * * *$ & $0.355^{* * *}$ & $2.339 * * *$ & -0.014 \\
Year Industry FE & $(5.08)$ & $(3.34)$ & $(14.45)$ & $(-0.33)$ \\
Customer Firm FE & $\mathrm{Y}$ & $\mathrm{Y}$ & $\mathrm{Y}$ & $\mathrm{Y}$ \\
$\mathrm{N}^{*}$ & $\mathrm{Y}$ & $\mathrm{Y}$ & $\mathrm{Y}$ & $\mathrm{Y}$ \\
Adj. R & 5485 & 6477 & 6422 & 6281 \\
\hline
\end{tabular}

* Number of observations after weighting

This table reports results of analyses investigating the effect of customer-supplier relationships that were likely formed with the help of personal connections on customer performance following the start of the supply-chain relationship. The sample consists of firm-year observations for all customer-supplier pairs in Compustat between 2000 and 2011, for which we have data on BoardEx $(N=18,804)$. Panel A reports descriptive statistics on the variable used in the analysis testing the effect of connected supply-chain relationships on a customer's operations. Panel B reports results of WLS regressions testing the association between personal connections and customer operations after the formation of supply-chain relationships. The dependent variable measuring customer operation is (1) column 1 - inventory volatility, (2) column 2 - cost of goods sold volatility, (3) column 3 - sales efficiency, and (4) column 4 - ROA. The personal-connection variable $(C O N N E C T E D)$ is constructed to take the value of 1 if either an educational connection $\left(C O N_{-} E D U\right)$ or a work-based connection (CON_WORK) exists. POST takes the value of 1 if the year falls in the post-supplychain-formation period and 0 otherwise. Variable definitions are provided in Appendix Table 10. Customer and year-industry fixed effects are included. Observations are weighted by the inverse of the number of suppliers for a customer in the sample. Coefficient estimates are reported in the top row, and t-statistics are reported in parentheses below. $* * *, * *$, and $*$ denote two-tailed significance at the $0.01,0.05$, and 0.10 levels, respectively.

The subscripts $i, j$, and $t$ index for customer $i$, supplier $j$, and year $t$. POST is an indicator variable that takes the value of 1 for years after the formation of a supply-chain relationship and 0 otherwise. The variable of interest is the interaction between CONNECTED and POST. We control for factors commonly used in the literature, such as customers' book-to-market ratio, leverage, and customer fixed effects. Following Feng et al. (2015), we add customer tangibility, age, and gross margin to the regression.

Table 9, Panel A, reports descriptive statistics for the variables used in the analysis. Each observation in the table represents a customer-year. Our sample spans over 12 years. The number of observations used in the regressions varies, due to data availability to compute the measures of efficiency. We find $17.5 \%$ of firm-year observations have connections, which is lower than $28.4 \%$ for customer-supplier pairs reported in Table 3. This lower percentage is due to the dilution caused by including customer firm-years before the formation of a connected supply-chain relationship, in which case CONNECTED takes the value of 0 . Panel $\mathrm{B}$ reports regression results. We use weighted least squares (WLS) to account for large customers (e.g., Walmart), which have multiple suppliers in the sample. To count each customer once, we weight each observation by the inverse of the number of suppliers of that customer in the sample. This way, each supplier is weighted by its relative impact on the customer, and 
we avoid problems of heteroskedasticity. The use of WLS reduces the number of observations in the regression analyses, compared to the number of observations reported in the summary statistics of Panel A.

The coefficient on POST is not significant across the specifications, implying firm operating efficiency does not change after transacting with an unconnected supplier. The interaction between CONNECTED and POST is, however, negative and significant for volatility of both inventory and cost of goods sold and positive and significant for sales efficiency and ROA. These results not only corroborate our main results, supporting the hypothesis that personal connections can mitigate information asymmetry in the supply chain but also highlight the real value of personal connections in improving a firm's operational efficiency. These results further suggest the role of personal connections in supplier choice is less likely due to currying favor, a motive that was found to affect supplier selection in the context of political connections. The reason is that, under the currying-favor view, we would have observed lower operating efficiency, following the formation of a personally connected supply chain.

\subsection{Additional analyses, sensitivity tests}

We conduct multiple sensitivity analyses, some of which are reported in the manuscript and others in the online appendix, to provide a high level of confidence in our interpretation of the empirical evidence. In the online appendix, we report results of the following additional analyses. To mitigate endogeneity concerns, due to omitted correlated variables, (1) we use an alternative sample based on propensity-score matching that matches firms according to the likelihood of connectedness (Table A2), (2) we use an alternative sample that eliminates the difference in the distance between supplier-customer pairs and nonsupplier-customer pairs (Table A4), and (3) we conduct the supplier-selection analysis including various additional fixed effects (Table A3). Our results are robust to these additional analyses.

To further mitigate reverse-causality concerns, we increase the required time gap between the start of the personal connection and the start of the business connection from two years to five years and up to 25 years in increments of five years (Table A5). To ensure our results are insensitive to the empirical choices we make, we conduct the supplier-selection analysis based on alternative samples that identify three or four nonsupplier vendor matches for each supplier, instead of two (Table A6), and alternative samples that include all four-digit SIC firms of the supplier as nonsupplier vendors (Table A7), or use 10-K text-based fixed industry classification (Hoberg and Philips Hoberg and Phillips 2010, Hoberg and Phillips 2016), instead of SIC (Table A8). Our results are insensitive to these alternative empirical choices.

Finally, we conduct supplier-selection analysis in the cross-section based on the existence of multiple vendors in close proximity to the customer to further illuminate the conditions under which personal connections might have a stronger effect. We show in Table A9 that the effect of personal connections is more pronounced when information asymmetry between customers and vendors are greater, that is, when there are few vendors in close proximity, lending further credence to our main findings. We also use the two-step Heckman procedure to conduct the procurement-contract analysis to address the sample-selection issue (Table A10). 


\section{Conclusion}

This study examines the role of personal connections in the selection of suppliers. We find that a customer is more likely to choose as its supplier a vendor to whom its executives are personally connected than a vendor without such connections. The effect of personal connections varies predictably across management ranks and functions, and the effect is more pronounced when information asymmetry is greater. These results are robust to multiple tests aimed at addressing endogeneity in the relation between personal connections and supplier selection. We also show personal connections are associated with less restrictive procurement contracts to suppliers and ultimately improve customer operating efficiency. Overall, our findings highlight that personal connections may help reduce transaction costs in supplier selection. Our research also adds to the emerging literature that examines the role of social connections in addressing information frictions and agency (Sapienza 2004; Engelberg et al. 2012; Duchin and Sosyura 2012). Our evidence in the supply chain setting comports with personal connections mitigating information frictions. Last, the COVID-19 crisis has significantly disrupted supply chains. It will be interesting and important to examine whether personal connections help counteract these disruptions and fostering a more resilient and robust supply chain network. We leave these questions for future research.

Before concluding the study, we would like to note a few limitations. First, our study focuses on supply chain relationships in the public company domain. Given that private firms are more informationally opaque, it is conceivable that personal connections might play a different, or even more important role in addressing information frictions among these firms. Second, as noted earlier, our findings should be interpreted with caution since we might not have fully addressed all possible endogenous issues. 


\section{APPENDIX A}

Table 10 Variable Definitions

\begin{tabular}{|c|c|}
\hline & Supplier-Selection Analyses \\
\hline SUPPLIER & $\begin{array}{l}\text { An indicator variable that takes the value of } 1 \text { for a customer-supplier pair } \\
\text { and } 0 \text { for a customer-nonsupplier vendor pair. }\end{array}$ \\
\hline CON_EDU & $\begin{array}{l}\text { An indicator variable that takes the value of } 1 \text { if at least one educational } \\
\text { connection exists between a vendor's executives and a customer's } \\
\text { executives and } 0 \text { for no such connections. To be coded as 1, executives of } \\
\text { the vendor and customer must have attended the same university for at } \\
\text { least one overlapping year and received the same degree (e.g., MBA). } \\
\text { This personal connection must have started more than two years before } \\
\text { the start of the customer-supplier relationship. }\end{array}$ \\
\hline CON_WORK & $\begin{array}{l}\text { An indicator variable that takes the value of } 1 \text { if at least one past work-based } \\
\text { connection exists between a vendor's executives and a customer's } \\
\text { executives and } 0 \text { for no such connections. To be coded as } 1 \text {, executives of } \\
\text { the vendor and the customer must have worked at the same organization } \\
\text { for at least one overlapping year before starting employment at the vendor } \\
\text { or at the customer, and this personal connection must have started more } \\
\text { than two years before the start of the customer-supplier relationship. }\end{array}$ \\
\hline CONNECTED & $\begin{array}{l}\text { An indicator variable that takes the value of } 1 \text { if at least one personal } \\
\text { connection exists between a vendor's executives and a customer's } \\
\text { executives and } 0 \text { for no such connections. To be coded as } 1 \text {, executives of } \\
\text { the vendor and the customer must have either an educational connection } \\
\left(C O N \_E D U_{i, j, t}\right) \text { or a past work-based connection }\left(\mathrm{CON}_{-} \text {WORK }_{\mathrm{i}, \mathrm{j}, \mathrm{t}}\right) \text { as } \\
\text { defined above. }\end{array}$ \\
\hline
\end{tabular}

\section{LARGEST_S}

IVY_LEAGUE_S

PHD_MASTERS_S

TANGIBILITY_S
CASH_S
SIZE_S/C
ROA_S
LEV_S
LOG_SALE_S
SALE_GROWTH_S
GM_S/C
PM_S
CAPEX_S
DAYS_INV_S
DAYS_AP_S

An indicator variable that takes the value of 1 if the vendor is one of the three largest sellers in a four-digit SIC industry (calculated as Compustat $\mathrm{SALE}_{\mathrm{t}} / \operatorname{sum}\left(\mathrm{SALE}_{\mathrm{t}}\right)$ in a four-digit SIC industry).

The ratio of a vendor's executives that hold a degree from an Ivy League university, Stanford University, Massachusetts Institute of Technology, University of Chicago, or California Technology Institute, University to the total number of the vendor's executives reported on BoardEx.

The ratio of the number of the vendor's executives that hold a master's, doctorate, or medical degree to the total number of the vendor's executives reported on BoardEx.

Net PPE to total assets of a vendor (Compustat PPENT $\mathrm{PT}_{t}$ ).

Cash to total assets of a vendor (Compustat $\mathrm{CHE}_{\mathrm{t}} / \mathrm{AT}_{\mathrm{t}}$ ).

The natural logarithm of a vendor's (a customer's) total book value of assets (Compustat $\mathrm{AT}_{\mathrm{t}}$ ).

Return on assets of a vendor (Compustat $\operatorname{OIBDP}_{t} /$ average $\left.\mathrm{AT}_{\mathrm{t}, \mathrm{t}-1}\right)$.

Leverage of a vendor (Compustat $\left.\left(\mathrm{DLC}_{\mathrm{t}}+\mathrm{DLTT}_{\mathrm{t}}\right) / \mathrm{AT}_{\mathrm{t}}\right)$.

The natural logarithm of a vendor's total sales (Compustat $\mathrm{SALE}_{\mathrm{t}}$ ).

Sales growth (Compustat $\left.\left(\mathrm{REVT}_{\mathrm{t}}-\mathrm{REVT}_{\mathrm{t}-1}\right) / \mathrm{REVT}_{\mathrm{t}}\right)$.

Gross margin (Compustat $\left.\left(\mathrm{SALE}_{\mathrm{t}}-\mathrm{COGS}_{\mathrm{t}}\right) / \mathrm{SALE}_{\mathrm{t}}\right)$.

Profit margin (Compustat $\mathrm{IB}_{\mathrm{t}} / \mathrm{REVT}_{\mathrm{t}}$ ).

Capital Expenditure Intensity (Compustat CAPX $\mathrm{AT}_{\mathrm{t}}$ ).

Days Inventory (Compustat $365^{*} \mathrm{INVT}_{\mathrm{t}} / \mathrm{COGS}_{\mathrm{t}}$ ).

Days AP (Compustat $365^{*} \mathrm{AP}_{\mathrm{t}} / \mathrm{COGS}_{\mathrm{t}}$ ). 
Table 10 (continued)

\begin{tabular}{ll}
\hline DAYS_AR_S & Days AR (Compustat $\left.365^{*} \mathrm{RECT}_{\mathrm{t}} / \mathrm{REVT}_{\mathrm{t}}\right)$. \\
PPE_TO_S & Property, Plant, and Equipment turnover $\left(\mathrm{Compustat} \mathrm{REVT}_{\mathrm{t}} / \mathrm{PPENT}_{\mathrm{t}}\right)$. \\
IHLD_S & Inventory holding period $\left(\mathrm{Compustat} \mathrm{INVT}_{\mathrm{t}} / \mathrm{AT}_{\mathrm{t}}\right)$. \\
NEGFCF_S & Indicator variable equal to 1 if free cash flow $\left(\mathrm{Compustat}_{\mathrm{OANCF}} \mathrm{CAPX}_{\mathrm{t}}\right)$ \\
& is negative and 0 otherwise. \\
RND S & $\mathrm{R} \& \mathrm{D}$ expense $\left(\right.$ Compustat $\left.\mathrm{XRD}_{\mathrm{t}} / \mathrm{AT}_{\mathrm{t}}\right)$.
\end{tabular}

AGE_S/C

DISTANCE

ABN_ACCRUALS_S

DURATION

DURATION_POST

DURATION PRE

CONNECTED EXEC

CONNECTED_FIRM

MKSH_S

AGE_EXEC

PROMOTION/RETIREMENT An indicator variable that takes the value of 1 if the executive departing is 65 years or older or if his or her next position is of the same rank or higher and the company is at least of the same size as the company he or she left.

\section{Procurement-Contracts Analysis}

RESTRICTIVENESS
The number of restrictive provisions on the supplier included in a procurement contract. The maximum number of provisions is six and includes product warranty, supplier-paid liability/property insurance, the customer's right to inspect supplier production facilities, pre-scheduled periodic meetings between the customer's and supplier's representatives, third-party certification, and third-party performance guarantee.

The shortest contract term in years allowed by the procurement contract. 
Table 10 (continued)

\begin{tabular}{|c|c|}
\hline WARRANTY & $\begin{array}{l}\text { An indicator variable that takes the value of } 1 \text { if the procurement contract } \\
\text { includes a product warranty provision and } 0 \text { otherwise. }\end{array}$ \\
\hline INSURANCE & $\begin{array}{l}\text { An indicator variable that takes the value of } 1 \text { if the procurement contract } \\
\text { includes a supplier-paid liability/property insurance provision and } 0 \\
\text { otherwise. }\end{array}$ \\
\hline INSPECTION & $\begin{array}{l}\text { An indicator variable that takes the value of } 1 \text { if the procurement contract } \\
\text { includes a customer's right to inspect the supplier's production facilities and } \\
0 \text { otherwise. }\end{array}$ \\
\hline MEETING & $\begin{array}{l}\text { An indicator variable that takes the value of } 1 \text { if the procurement contract } \\
\text { includes a provision on pre-scheduled periodic meetings between the } \\
\text { customer's and supplier's representatives and } 0 \text { otherwise. }\end{array}$ \\
\hline EXCLUSIVITY & $\begin{array}{l}\text { An indicator variable that takes the value of } 1 \text { for procurement contracts that } \\
\text { specify exclusivity of the customer/supplier and } 0 \text { otherwise. }\end{array}$ \\
\hline \multirow[t]{2}{*}{ ALT_Z_S } & $\begin{array}{l}\text { Supplier's Altman Z-Score calculated as }(\text { Compustat }): 1.2 *\left(\left(\mathrm{INV}_{\mathrm{t}}+\mathrm{RECT}_{\mathrm{t}}\right.\right. \\
\left.\left.\mathrm{AP}_{\mathrm{t}}\right) / \mathrm{AT}_{\mathrm{t}}\right)+1.4^{*}\left(\mathrm{RE}_{\mathrm{t}} / \mathrm{AT}_{\mathrm{t}}\right)+3.3 *\left(\mathrm{EBIT}_{\mathrm{t}} / \mathrm{AT}_{\mathrm{t}}\right)+0.6 *\left(\mathrm{MKVAT}_{\mathrm{t}} / \mathrm{LT}_{\mathrm{t}}\right)+ \\
0.999 *\left(\mathrm{SALE}_{\mathrm{t}} / \mathrm{AT}_{\mathrm{t}}\right)\end{array}$ \\
\hline & Customers' Operation Analysis \\
\hline POST & $\begin{array}{l}\text { An indicator variable that takes the value of } 1 \text { for all years after the initiation } \\
\text { of customer-supplier relationship and } 0 \text { otherwise. }\end{array}$ \\
\hline INV_STD_C & 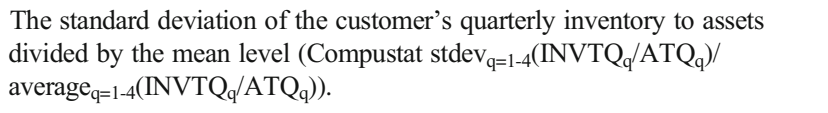 \\
\hline COGS_STD_C & $\begin{array}{l}\text { The standard deviation of the customer's quarterly cost of goods sold to } \\
\text { assets divided by the mean level (Compustat } \operatorname{stdev}_{\mathrm{q}=1-4}\left(\operatorname{COGSQ}_{\mathrm{q}} / \mathrm{SALEQ}_{\mathrm{q}}\right) / \\
\left.\text { average }_{\mathrm{q}=1-4}\left(\mathrm{COGSQ}_{\mathrm{q}} / \mathrm{SALEQ}_{\mathrm{q}}\right)\right) \text {. }\end{array}$ \\
\hline ROA_C & Return on assets of the customer (Compustat $\mathrm{OIBDP}_{\mathrm{t}} /$ average $\left.\mathrm{AT}_{\mathrm{t}, \mathrm{t}-1}\right)$ \\
\hline SALE_ASSET_C & $\begin{array}{l}\text { The ratio of sales to assets at the customer (Compustat } \mathrm{SALE}_{\mathrm{t}} / \text { average } \\
\left.\mathrm{AT}_{\mathrm{t}, \mathrm{t}-1}\right) \text {. }\end{array}$ \\
\hline BTM_C & $\begin{array}{l}\text { Ratio of book value of equity to market value of equity of the customer } \\
\left(\text { Compustat } \mathrm{SEQ}_{\mathrm{t}} / \mathrm{MKVALT}_{\mathrm{t}}\right) \text {. }\end{array}$ \\
\hline LEV_C & Leverage of a customer (Compustat $\left.\left(\mathrm{DLC}_{\mathrm{t}}+\mathrm{DLTT}_{\mathrm{t}}\right) / \mathrm{AT}_{\mathrm{t}}\right)$. \\
\hline TANGIBILITY_C & Net PPE to total assets of a customer (Compustat PPENT $/ \mathrm{AT}_{\mathrm{t}}$ ). \\
\hline
\end{tabular}

All variables are winsorized at the first and 99th percentiles. All ratios are bounded by -1 and 1

Supplementary information The online version contains supplementary material available at https://oi. org/10.1007/s11142-020-09578-1.

Acknowledgements We thank Lakshmanan Shivakumar (editor), two anonymous reviewers, seminar participants at NYU Stern, Tel Aviv University, University of Massachusetts Boston, Temple University, University of Minnesota, Rotman School of Management, and the Three School conference at Baruch College for helpful comments and suggestions. We are grateful for financial support from the Research Foundation of CUNY. All errors are our own. 


\section{References}

Aboody, D., J. Hughes, and J. Liu. 2005. Earnings quality, insider trading, and cost of capital. Journal of Accounting Research 43: 651-673.

Ai, C.R., and E.C. Norton. 2003. Interaction terms in logit and probit models. Economics Letters 80 (1): $123-$ 129.

Anupindi, R., and R. Akella. 1993. Diversification under supply uncertainty. Management Science 39 (8): 944-963.

Babich, V. 2006. Vulnerable options in supply chains: Effects of supplier competition. Naval Research Logistics 53 (7): 656-673.

Babich, V., Aydin, G., Brunet, P.Y., Keppo, J., and Saigal, R. 2005. Risk, financing, and the optimal number of suppliers. Working paper.

Babich, V., A.N. Burnetas, and P.H. Ritchken. 2007. Competition and diversification effects in supply chains with supplier default risk. M\&SOM 9 (2): 123-146.

Ball, R., R.M. Bushman, and F.P. Vasvari. 2008. The debt-contracting value of accounting information and loan syndicate structure. Journal of Accounting Research 46: 247-287.

Bauer, A., D. Henderson, and D. Lynch. 2018. Supplier internal control quality and the duration of customersupplier relationships. The Accounting Review 93: 59-82.

Beatty, A., S. Liao, and J. Weber. 2010. Financial reporting quality, private information, monitoring, and the lease-versus-buy decision. The Accounting Review 85: 1215-1238.

Beil, D.R. 2010. Supplier selection. Wiley Encyclopedia of operations research and management science. John Wiley \& Sons, Inc.

Bevilacqua, M., F.E. Ciarapica, and G. Giacchetta. 2006. A fuzzy-QFD approach to supplier selection. Journal of Purchasing and Supply Management 12 (1): 14-27.

Boyarchenko, N., and Costello, A.M. 2015. Counterparty risk in material supply contracts. Working paper.

Cannon, J.P., and C. Homburg. 2001. Buyer-supplier relationships and customer firm costs. Journal of Marketing 65: 29-43.

Çebi, F., and D. Bayraktar. 2003. An integrated approach for supplier selection. Logistics Information Management 16 (6): 395-400.

Chen, D., Liu, M., and Ma, T. 2015. The real effect of customer accounting quality-trade credit and suppliers' cash holdings. Working paper.

Chen, Y.M., and P.N. Huang. 2007. Bi-negotiation integrated AHP in suppliers selection. Benchmarking: An International Journal 14 (5): 575-593.

Chou, S.Y., and Y.H. Chang. 2008. A decision support system for supplier selection based on a strategyaligned fuzzy SMART approach. Expert Systems with Applications 34 (4): 2241-2253.

Cohen, L., A. Frazzini, and C. Malloy. 2008. The small world of investing: Board connections and mutual fund returns. Journal of Political Economy 116 (5): 951-979.

Cohen D.A., and Li, B. 2014. Why do firms hold less cash? A customer base explanation. Working paper.

Cohen D.A., and Li, B. 2017. Customer-base concentration, profitability and the information environment: The U.S. government as a major customer. Working paper.

Costello, A.M. 2013. Mitigating incentive conflicts in inter-firm relationships: Evidence from long-term supply contracts. Journal of Accounting and Economics 56: 19-39.

Costello, A.M. 2017. Credit market disruptions and liquidity spillover effects in the supply chain. Working paper.

Dechow, P., R. Sloan, and A. Sweeney. 1995. Detecting earnings management. The Accounting Review 70: 193-225.

Demirtas, E.A., and Ö. Üstün. 2009. Analytic network process and multi-period goal programming integration in purchasing decisions. Computer and Industrial Engineering 56 (2): 677-690.

Duchin, R., and D. Sosyura. 2012. The politics of government investment. Journal of Financial Economics 106 (1): 24-48.

Duchin, R., and D. Sosyura. 2013. Divisional managers and internal capital markets. Journal of Finance 68 (2): $387-429$.

Duchin, R., and D. Sosyura. 2014. Safer ratios, riskier portfolios: Banks response to government aid. Journal of Financial Economics 113: 1-28.

Ellis, J.A., C.E. Fee, and S.E. Thomas. 2012. Proprietary costs and the disclosure of information about customers. Journal of Accounting Research 50: 685-727.

Engelberg, J., P. Gao, and P. Parsons. 2012. Friends with money. Journal of Financial Economics 103: 169188. 
Erel, I., Stern, L., Tan, C., and Weisbach, M. 2019. Selecting directors using machine learning. Working paper.

Feng, M., C. Li, S. McVay, and H. Skaife. 2015. Does ineffective internal control over financial reporting affect a firm's operations? Evidence from firms' inventory management. The Accounting Review 90 (2): $529-557$.

Fracassi, C., and G. Tate. 2012. External networking and internal firm governance. Journal of Finance 67 (1): 153-194.

Fracassi, C. 2017. Corporate finance policies and social networks. Management Science 63 (8): 2420-2438.

Gao, X., Wong, T. J, Xia, L., and Yu., G. 2014. Friends with close ties: Asset or liability? Evidence from the investment decisions of mutual funds in China. Working paper.

Hasija, S., E. Pinker, and R. Shumsky. 2008. Call center outsourcing contracts under information asymmetry. Management Science 54 (4): 793-807.

Ho, W., X. Xu, and P. Dey. 2010. Multi-criteria decision-making approaches for supplier evaluation and selection: A literature review. European Journal of Operational Research 202: 16-24.

Hoberg, G., and G. Phillips. 2010. Product market synergies and competition in mergers and acquisitions: A text-based analysis. Review of Financial Studies 23 (10): 3773-3811.

Hoberg, G., and G. Phillips. 2016. Text-based network industries and endogenous product differentiation. Journal of Political Economy 124: 1423-1465.

Hortacsu, A., F. Martinez-Jerez, and J. Douglas. 2009. The geography of trade in online transactions: Evidence from eBay and MercadoLibre. American Economic Journal: Microeconomics 1: 53-74.

Hui, K.W., Klasa, S., and Yeung., P.E. 2012. Corporate suppliers and customers and accounting conservatism. Journal of Accounting and Economics 53, 115-135.

Ittner, C.D., D.F. Larcker, V. Nagar, and M.V. Rajan. 1999. Supplier selection, monitoring practices, and firm performance. Journal of Accounting and Public Policy 18: 253-281.

Kale, J., and H. Shahrur. 2007. Corporate capital structure and the characteristics of supplier and customer markets. Journal of Financial Economics 83 (2): 321-365.

Kouvelis, P., and J.M. Milner. 2002. Supply chain capacity and outsourcing decisions: The dynamic interplay of demand and supply uncertainty. IIE Transactions 34: 717-728.

Liu, J., F.Y. Ding, and V. Lall. 2000. Using data envelopment analysis to compare suppliers for supplier selection and performance improvement. Supply Chain Management: An International Journal 5 (3): $143-150$.

Liu, F.H.F., and H.L. Hai. 2005. The voting analytic hierarchy process method for selecting supplier. International Journal of Production Economics 97 (3): 308-317.

McCann, D. 2014. Double duty. http://ww2.cfo.com/leadership/2014/05/double-duty/ (accessed 13 September 2019).

McCarthy, I.P., B.S. Silvestre, and J.H. Kietzmann. 2013. Understanding outsourcing contexts through information asymmetry and capability fit. Production, Planning \& Control 24 (4-5): 277-283.

McCracken, J. 2006. Ford gets cut off by top supplier as Detroit squeezes parts makers. The Wall Street Journal (Oct 18).

Muralidharan, C., N. Anantharaman, and S.G. Deshmukh. 2002. A multi-criteria group decision-making model for supplier rating. Journal of Supply Chain Management 38 (4): 22-33.

Noordewier, T., G. John, and J. Nevin. 1990. Performance outcomes of purchasing arrangements in industrial buyer-vendor relationships. Journal of Marketing 54: 80-93.

Perçin, S. 2006. An application of the integrated AHP-PGP model in supplier selection. Measuring Business Excellence 10 (4): 34-49.

Sapienza, P. 2004. The effects of government ownership on bank lending. Journal of Financial Economics 72 (2): $357-384$.

Sarkis, J., and Talluri., S. 2002. A model for strategic supplier selection. The Journal of Supply Chain Management 38(1), 18-28.

Serel, D.A., M. Dada, and H. Moskowitz. 2001. Sourcing decisions with capacity reservation contracts. European Journal of Operations Research 131: 635-648.

Sevkli, M., S.C.L. Koh, S. Zaim, M. Demirbag, and E. Tatoglu. 2007. An application of data envelopment analytic hierarchy process for supplier selection: A case study of BEKO in Turkey. International Journal of Production Research 45 (9): 1973-2003.

Schmidt, B. 2015. Costs and benefits of "friendly" boards during mergers and acquisitions. Journal of Financial Economics 117 (2): 424-447.

Tomlin, B. 2006. On the value of mitigation and contingency strategies for managing supply chain disruption risks. Management Science 52 (5): 639-657. 
Verrecchia, R.E., and J. Weber. 2006. Redacted disclosure. Journal of Accounting Research 44 (September): 791-814.

Weber, C.A., J.R. Current, and A. Desai. 2000. An optimization approach to determining the number of vendors to employ. Supply Chain Management: An International Journal 5 (2): 90-98.

Winter, S. 1988. On Coase, competence, and the corporation. Journal of Law, Economics and Organization 4 (1): 163-180.

Wittenberg-Moerman, R. 2008. The role of information asymmetry and financial reporting quality in debt trading: Evidence from the secondary loan market. Journal of Accounting and Economics 46 (2-3): 240260.

Yang, Z. 2009. Supply risk and asymmetric information. Working paper.

Publisher's note Springer Nature remains neutral with regard to jurisdictional claims in published maps and institutional affiliations.

\section{Affiliations}

\section{Ting Chen ${ }^{1} \cdot$ Hagit Levy ${ }^{2} \cdot$ Xiumin Martin $^{3} \cdot$ Ron Shalev $^{4}$}

1 College of Management, University of Massachusetts Boston, Boston, MA, USA

2 Zicklin School of Business, Baruch College \& UTSC, New York, NY, USA

3 Olin School of Business, Washington University in St. Louis, St. Louis, MO, USA

4 Rotman School of Management \& UTSC, University of Toronto, Toronto, Canada 